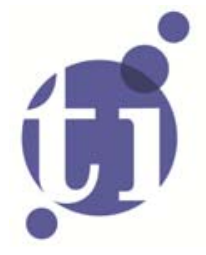

\title{
Transformations of Industrial Heritage: Insights into External Effects on House Prices
}

\author{
Mark van Duijna,b,c \\ Jan Rouwenda/a,c,d \\ Richard Boersemae
}

a Faculty of Economics and Business Administration, VU University Amsterdam, the Netherlands;

b University of Groningen, the Netherlands;

c Tinbergen Institute, the Netherlands;

d Amsterdam School of Real Estate, the Netherlands;

e Colliers International, Amsterdam. 
Tinbergen Institute is the graduate school and research institute in economics of Erasmus University Rotterdam, the University of Amsterdam and VU University Amsterdam.

More TI discussion papers can be downloaded at http://www.tinbergen.nl

Tinbergen Institute has two locations:

Tinbergen Institute Amsterdam

Gustav Mahlerplein 117

1082 MS Amsterdam

The Netherlands

Tel.: +31(0)205251600

Tinbergen Institute Rotterdam

Burg. Oudlaan 50

3062 PA Rotterdam

The Netherlands

Tel.: +31(0)10 4088900

Fax: $+31(0) 104089031$

Duisenberg school of finance is a collaboration of the Dutch financial sector and universities, with the ambition to support innovative research and offer top quality academic education in core areas of finance.

DSF research papers can be downloaded at: http://www.dsf.nl/

Duisenberg school of finance

Gustav Mahlerplein 117

1082 MS Amsterdam

The Netherlands

Tel.: +31(0)20 5258579 


\title{
Transformations of industrial heritage: Insights into external effects on house prices*
}

\author{
Mark van Duijnna,b,c, Jan Rouwendala,c,d \& Richard Boersema \\ ${ }^{a}$ Department of Spatial Economics, Faculty of Economics and Business Administration, VU University, De Boelelaan 1105, 1081 HV \\ Amsterdam, The Netherlands \\ b Department of Economic Geography, and Population Research Centre, Faculty of Spatial Sciences, University of Groningen, \\ Landleven 1,9747 AD Groningen, The Netherlands \\ c Tinbergen Institute, Gustav Mahlerplein 117, 1082 MS Amsterdam, The Netherlands \\ d Amsterdam School of Real Estate, Jollemanhof 5, 1019 GW Amsterdam, the Netherlands \\ *Corresponding author: mark.van.duijn@rug.nl
}

\begin{abstract}
Local policy makers seek ways to deal with abandoned industrial heritage in their jurisdictions. Much is demolished, but in some cases considerable investments are made to preserve the cultural aspects of industrial sites. The renewal plans are usually designed to stimulate urban renewal in the vicinity of these sites. Little seems to be known about the effectiveness of these policies and in this paper, we study whether the redevelopment of five industrial heritage sites caused positive external effects by investigating the development of house prices in nearby residential areas. We use a quasi-experimental design by comparing quality-adjusted house prices before the start, between the start and the completion and after the completion of the transformation. We find substantial effects of one site, which is the bestknown example of renovated industrial heritage in the Netherlands, but much smaller or no effects for the other sites. We also model the decay of these effects over time and space. We find different decay effects for each case. We conclude that industrial heritage sites do not necessarily cause negative external effects. If there are negative external effects present they disappear at the start of the transformation of the industrial heritage site, suggesting anticipation effects. Also, positive external effects on house prices after the redevelopment of industrial heritage are not necessarily present. The details of the transformation project (e.g. location, size of the site, size of the investment, focus on interior or exterior investments) seem to be important determinants that may cause the existence of positive external effects.
\end{abstract}

Key words: Industrial heritage, redevelopment, urban revitalization, external effects, hedonic prices

JEL classifications: C21, D62, H43, R0 
Many manufacturing firms left the urban sites in which they located in the $19^{\text {th }}$ or early $20^{\text {th }}$ century. As a result, most industrial sites lost their original function and got abandoned. Policy makers search to deal with the unused land. Local policy makers can decide to 1) leave it as it is, 2) demolish the existing buildings and redevelop the land, or 3) renovate the existing buildings while simultaneously making them suitable for new functions. The last alternative is especially attractive when the existing buildings have heritage value. The idea to renovate old factories became popular in connection with Jacob's (1961) ideas that new ideas need old buildings and, later, Florida's (2002) creative city concept. Many policy makers now believe that renovation of an abandoned industrial site is a tool to upgrade neighborhoods by attracting higher educated residents, firms from the creative sector and tourists. There are many examples of such redeveloped industrial heritage sites throughout the world: former power plant site, Erie, PA, US; Rheinauhafen, Cologne, Germany; King's Cross, London, UK; Kings Waterfront, Liverpool, UK; Gasometers, Vienna, Austria. In the Netherlands only, more than 200 transformation projects are finished that redevelop an industrial area, which has lost its original function, and many more projects are ongoing or planned. ${ }^{1}$

It seems plausible that the redevelopment of industrial heritage has a positive (external) effect on the living environment of surrounding residential areas, as is often argued by policymakers. ${ }^{2}$ However, the evidence underlying this opinion is often limited to impressions and references to well-known examples that are generally considered as success stories. There does not appear to exist much research that underlies this opinion. Maliene et al. (2012) argue, based on descriptive statistics, that the redevelopment of these brownfield sites has the potential to promote the urban renaissance. They state that these redeveloped brownfield sites attract people, predominantly for the retail and leisure facilities and the attractiveness of the location. They also warn local policy makers that each brownfield site is unique and that there is no 'one-size-fits-all' recipe for success. However, their study lacks detailed empirical research to provide evidence on these matters. More attention has been given to the redevelopment of brownfield sites in general; see e.g. Linn (2013). Linn (2013) focuses on the certification that owners of such sites are not subject to federal or state liability for contamination of these sites. Our attention is more focused on the heritage aspects and the associated potential of generating external effects.

In this paper we present an analysis of the impact of five large renovation projects in the Netherlands concerning industrial heritage on house prices in the surrounding neighborhoods. One of these projects is the success story of Dutch renovation activities: the Westergasfabriek in

\footnotetext{
${ }^{1}$ An overview of each tranformation project can be found at http://www.kennisbankherbestemming.nu/

${ }^{2}$ For example, see SBR \& Aedes (2010) or CPB \& PBL (2010).
} 
Amsterdam. The other four are also well-known and generally considered as exemplary for successful renovation of industrial heritage sites that lost their original function. The focus of interest will be on the measurement of the external effects and the possible existence of general properties of these effects, for instance on their size and distance decay.

Our paper contributes to the economic literature that investigates urban revitalization policies (e.g. Ahlfeldt et al., 2013b; Brooks \& Phillips, 2007; Koster \& Van Ommeren, 2013; RossiHansberg et al., 2010). Most of this literature is focused on investments in housing and living quality of a specific target area. Present paper is different in many ways. We study the impact of investments in industrial heritage and not directly into housing. We distinguish between external effects occurring before, between the start and the completion, and after the completion of the redevelopment of industrial heritage on house prices of nearby residential areas. We use a quasi-experimental hedonic approach to see whether there are indeed external effects caused by the industrial heritage and how large those effects are on the house prices of nearby residential areas. We pay special attention to defining the target and control area. This study aims at providing more insights in the possible external effects of industrial heritage sites. Measurement of the size of these external effects clearly provides important information for local policy makers who decide how to redevelop used land.

This paper is also connected to a larger, more general, stream of literature that investigates the value of urban amenities (e.g. Ahlfeldt, 2011; Brueckner, Thisse \& Zenou, 1999; Carlino \& Coulson, 2004; Chen \& Rosenthal, 2008; Cheshire \& Sheppard, 1995; Ioannides, 2003). This literature argues that urban amenities have become increasingly important to the attractiveness of the urban areas and that especially higher educated households are attracted to the city center. This phenomenon is argued to be the driving force behind the economic prosperity of cities (Carlino \& Saiz, 2008; Glaeser et al., 2001).

The five cases that we study are listed in Table 1. For each of them we compare house prices in nearby residential areas before the start, between the start and the completion of the transformation period and afterwards. We make use of a rich dataset of housing transactions and structural characteristics of the sold properties provided by the Dutch Association of Real Estate Agents (NVM) that covers the period 1995 to 2011. Our findings suggest that in general negative external effects disappear when the transformation starts. This also implies that there are anticipation effects. Positive external effects do not necessarily arise after the redevelopment. It seems that positive external effects only arise when certain criteria are met regarding the location, the size of the site, the size of the investment, and other transformation details. The distance decay of the external effects differs for each case. This suggests a considerable amount of heterogeneity in the impact of redevelopment of industrial heritage. This also suggests that policy makers who want to copy a 'successful' transformation project 
must be aware that each project is unique regarding the location, investment and other details of the transformation project.

The remainder of this paper is organized as follows. Section 2 provides some theoretical background on external effects and brief descriptions on the cases of redeveloped industrial heritage sites. Section 3 introduces the methodology used in our analysis. The data and some descriptive statistics are presented in Section 4. Estimation results are reported and discussed in Section 5. The paper ends with a summary of the key findings and conclusions.

Table 1. Overview transformations of industrial heritage

\begin{tabular}{|c|c|c|c|c|c|c|c|}
\hline Case & & Original function & New function & $\begin{array}{r}\text { Start trans- } \\
\text { formation } \\
\text { year }\end{array}$ & $\begin{array}{r}\text { End trans- } \\
\text { formation } \\
\text { year }\end{array}$ & $\begin{array}{r}\text { Surface } \\
\text { (ha) }\end{array}$ & $\begin{array}{r}\text { Costs (in } \\
\text { million } \\
\text { euros) }\end{array}$ \\
\hline $\begin{array}{l}\text { Westergasfabriek } \\
\text { Amsterdam } \\
\text { Populatie: } 810 \mathrm{k}\end{array}$ & WG & Gas factory & $\begin{array}{l}\text { Multifunctional: big } \\
\text { events, art exhibitions, } \\
\text { firms from the creative } \\
\text { sector, park }\end{array}$ & 2000 & 2003 & 13 & 66.5 \\
\hline $\begin{array}{l}\text { Villa Augustus } \\
\text { Dordrecht } \\
\text { Populatie: } 280 \mathrm{k}\end{array}$ & VA & Water tower & $\begin{array}{l}\text { Multifunctional: hotel, } \\
\text { restaurant, garden }\end{array}$ & 2005 & 2007 & 1.8 & 6 \\
\hline $\begin{array}{l}\text { Zaanse Chocoladefabriek } \\
\text { Zaandam } \\
\text { Populatie: 73k }\end{array}$ & ZC & $\begin{array}{l}\text { Bread / Chocolate } \\
\text { factory }\end{array}$ & $\begin{array}{l}\text { Multifunctional: firms } \\
\text { from the creative sector, } \\
\text { restaurant, fitness school }\end{array}$ & 2004 & 2009 & 1.9 & 10 \\
\hline $\begin{array}{l}\text { DRU Cultuurfabriek } \\
\text { Ulft } \\
\text { Populatie: } 11 \mathrm{k}\end{array}$ & DC & Iron foundry & $\begin{array}{l}\text { Multifunctional: local } \\
\text { events, theater, library, } \\
\text { art exhibitions }\end{array}$ & 2005 & 2009 & 14 & 14 \\
\hline $\begin{array}{l}\text { Wooncomplex Tricot } \\
\text { Winterswijk } \\
\text { Populatie: } 24 \mathrm{k}\end{array}$ & WT & Textile factory & $\begin{array}{l}\text { Residential housing and } \\
\text { cultural function: local } \\
\text { events }\end{array}$ & 2003 & 2006 & 0.9 & 21 \\
\hline
\end{tabular}

Note: This is an arbitrary selection based on 210 cases of redevelopment projects in the Netherlands. Our selection is based on size, popularity and on the cultural heritage aspects of the redevelopment project.

Source: www.kennisbankherbestemming.nu

\section{$2 \quad$ Background}

This section provides some theoretical background on external effects and briefly describes the Dutch cases of industrial heritage redevelopment that are investigated in this paper including some statistics.

\subsection{Theoretical background}

Existing buildings deteriorate over time if they are not maintained properly. Since maintenance decisions are spatially correlated, the quality of the whole neighborhood may decrease over time. There is a large stream of literature investigating the depreciation (and renewal) of urban areas (e.g. Brueckner \& Rosenthal, 2009; Coulson \& Bond, 1990; Harding et al., 2007; Rosenthal, 
2008; Smith, 2004). Abandoned industrial sites are often large and may well have a negative impact on the neighborhoods in which they are located and become a disamenity for the nearby residential areas. We focus on industrial sites with cultural, historic aspects that policy makers prefer to preserve. When investments are made in the renewal of such industrial heritage sites, they are primarily focused on preserving the heritage value. It is often the case that the real estate of industrial heritage sites are listed built monuments and that it is not allowed to make significant changes to the exterior of the real estate to preserve the heritage value. The listed status implies that the site is eligible for subsidies to restore and maintain the building and they are usually a substantial part of the investments in industrial heritage. Restoration transforms a dilapidated building into a bright one and this may reasonably be expected to have a positive impact on the quality of the surrounding neighborhood.

Apart from the real estate, the redevelopment of the rest of the industrial site could be expected to generate additional external effects. For instance, in the Netherlands, large parts of the sites are often transformed into public green which is often scarce in the $19^{\text {th }}$ and early $20^{\text {th }}$ century neighborhoods where most of these sites are located.

In this paper, we investigate three types of external effects on house prices. First, we investigate whether the industrial heritage site was a disamenity for the nearby residential area before the start of the transformation. It might be that the presence of the industrial heritage site generates negative external effects on house prices and that this negative effect decreases over space. Second, we check for anticipation effects between the start and the completion of the transformation project. One could argue that households anticipate house prices to increase nearby these industrial heritage sites that will be redeveloped. Third, we investigate whether the investments made in industrial heritage sites generate positive external effects on house prices of nearby houses. It is expected that positive externalities emerge if 1) the redevelopment contains significant (positive) changes in the exterior of the industrial heritage site, like building attractive new residential houses or creating parks on the industrial terrain, or if 2) the redevelopment replaces a disamenity, like abandoned buildings and contaminated soil. ${ }^{3}$

We believe that the impact of the redevelopment of industrial heritage is likely to differ between sites because of the heterogeneity in the details of the transformation projects. The exact location is likely to play a major role, but also the size of the site, the size of the investment, and whether the investment is made into the interior or the exterior of the site might have an impact as well. This may be the background of the lack of consensus in the literature on the (external) effect of housing and other real estate investments. We avoid these problems by investigating the redevelopment of industrial heritage sites separately. We follow up on this in the next section.

\footnotetext{
${ }^{3}$ For a more extensive overview on the different kind of external effects caused by (housing) investments, see Schwartz et al. (2006).
} 


\subsection{Selection of redeveloped industrial heritage sites}

The following cases will be discussed in this paper: Westergasfabriek (Amsterdam), Zaanse Chocoladefabriek (Zaandam), Villa Augustus (Dordrecht), DRU Cultuurfabriek (Ulft), and Wooncomplex Tricot (Winterswijk). The projects we selected are spread over the country. All are well-known redevelopment projects that have been carried out in the past two decades in the Netherlands. Decisions to redevelop each of these industrial heritage sites were taken independently from each other by local governments. In all cases the focus was on the preservation of the historical value of each site.

The Westergasfabriek, a former gas factory, is the best-known example of an industrial redevelopment project and is perceived as highly successful. The transformation included a large clean-up of the polluted soil, the creation of a large park, and the renovation of the real estate. Its close location to the center of Amsterdam has certainly contributed to the demand for entrepreneurial and recreation space at this site. The impact on the neighborhood in which it is located has not been studied thus far. Two other projects are located in medium sized towns: the Zaanse Chocoladefabriek (= chocolate factory) in Zaandam which is located close to Amsterdam, and Villa Augustus, a former water tower in Dordrecht, which is located close to Rotterdam. The other two projects are in small towns located in the eastern part of the Netherlands. One is a former iron foundry at Ulft which is now known as DRU Cultuurfabriek (= culture factory). The other is a former textile factory in Winterswijk which has been transformed into a modern residential area known as Wooncomplex Tricot.

Villa Augustus and Wooncomplex Tricot are specific cases where there have been some large changes on the exterior of the former industrial heritage site but the investments made were not very substantial relative to the Westergasfabriek (see Table 1). On the other hand, the Zaanse Chocoladefabriek and DRU Cultuurfabriek had less or no changes on the exterior of the site, but instead large changes on the interior of the real estate. ${ }^{4}$ In the technical appendix, there is more information on each of the redeveloped industrial heritage site.

\section{$3 \quad$ Methodology}

In this paper, we - separately - investigate the external effects that influence house prices in surrounding residential areas before, between the start and completion, and after the completion of the redevelopment of several industrial heritage sites in the Netherlands. By definition, externalities do not have observable market prices. The value attached to them must

${ }^{4}$ There are plans to redevelop the land around the DRU Cultuurfabriek that focus on the exterior of the site, but are not conducted yet. 
therefore be measured in an indirect way. We use house prices in the vicinity of the sites for that purpose, and therefore have to face the challenge that it is not obvious which areas may have received an external effect of the redevelopment and how to disentangle it from other influences that acted simultaneously on the housing price. We therefore pay careful attention to defining the target and control area. It is plausible that nearby houses got 'treatment', in the sense that the prices of these houses may have possibly been influenced by the external effects from the redevelopment of an industrial site. These nearby houses are then in the 'target' group, but it is not a priori obvious what is nearby and what is not. Besides the baseline specification that will be discussed below, we also discuss an alternative, more flexible, specification that allows to define the reach of the target area. In a (quasi-)experimental setup, it is important that the 'target' and 'control' group are identical, except for the 'treatment' variable, to find consistent estimators for the effect of the 'treatment'. In this section, we present our empirical strategy where we address these problems.

\subsection{Baseline specification}

We start with the standard hedonic framework of Rosen (1974). We observe transaction prices, year of transaction, distance to the industrial heritage site, various housing characteristics and some neighborhood characteristics. The most straightforward approach to identify external effects would be to regress the prices on the distance to the nearby industrial heritage site and the interaction between the year of transformation of the industrial heritage and the distance, controlling for housing characteristics, such as floor area and number of rooms, and neighborhood characteristics, such as population density and share of migrants. If there are any external effects caused by the redevelopment of the industrial heritage site, one would expect a significant result on the interaction variable. However, this approach has important shortcomings. First, this model does not account for possible anticipation effects. Second, this approach leads to one coefficient that captures the external effect, which is then an average (linear) effect depending on the average distance to the redeveloped industrial heritage site. Third, the external effects are likely to differ between different transformation projects. Fourth, it is likely that there are more forces that influence house prices and, when unobserved, they may cause omitted variable bias.

To address these problems, we use and extend the model specification that is developed by Schwartz et al. (2006). Schwartz et al. (2006) specify a model to identify external effects caused by housing investments. In our case, the investments in industrial heritage sites are investigated for each site separately. The baseline specification - closely related to Schwartz et al. (2006) - is defined as: 


$$
\begin{aligned}
\ln \left(P_{i j t}\right)= & \sum_{s=1}^{S} \alpha_{s} R_{i t r s}+\sum_{s=1}^{S} \theta_{s} R_{i t r s} D_{i}+\sum_{s=1}^{S} \varphi_{s} R_{i t r s} D_{i}^{2}+ \\
& \sum_{k=1}^{K} \beta_{k} X_{k i}+\gamma_{t} Y_{t}+\pi_{j} N_{j}+\varepsilon_{i t}
\end{aligned}
$$

where $P_{i j t}$ is the house price transactions of property $i$ that is located in neighborhood $j$ at transaction year $t$; $R_{\text {itrs }}$ is set of variables (distance ring dummies and a trend) that depend on where property $i$ is located, the year of transaction $t$, and the treatment radius $r$ (described in more detail below); $D_{i}$ is the Euclidean or 'crow' distance in meters from the sold property to the industrial heritage site; $X_{k i}$ are structural characteristics $k$ of property $i$, which are described in section 4; $Y_{t}$ a dummy variable taking one for year $\mathrm{t}$ and zero otherwise; $N_{j}$ is a neighborhood dummy variable taking one for neighborhood $j$ and zero otherwise; $\varepsilon_{t}$ is an idiosyncratic error term. $\alpha_{s}, \theta_{s}, \varphi_{s}, \beta_{k}, \gamma_{t}$, and $\pi_{j}$ are parameters to be estimated. Note that we use separate regressions for different transformation projects. This allows us to test the heterogeneity of the external effects for the different cases. In addition, one does not have to control for location*time fixed effects. ${ }^{5}$

We specify four $(\mathrm{S}=4)$ different variables $\left(R_{\text {itrs }}\right)$ that indicates distance ring dummies and a trend. These variables allow us to capture the external effect of redeveloping industrial heritage sites. First, we include a distance ring dummy (s=BEFORE) if the location of property $i$ falls within the treatment radius $r$. The coefficient of the BEFORE dummy can (eventually) be interpret as the (negative) external effect of the abandoned industrial heritage site before transformation. Second, we include a dummy (s=BETWEEN) if the criteria of the BEFORE dummy is met and the transaction year of the sold property is between the start and the completion of the transformation. The BETWEEN dummy picks up some of the anticipation effects. ${ }^{6}$ Third, we include a dummy (s=AFTER) if the criteria of the BEFORE dummy is met and the transformation year of the sold property is after the completion of the transformation. This is the main variable of interest showing whether there are external effects after the transformation is complete within the treatment radius. Fourth and last, we include a variable ( $\mathrm{s}=$ TREND) that captures the time difference between the transaction and the completion of the transformation if the criteria of the AFTER dummy is met. This allows us to check whether the degree of the external effects changes over time.

Each of these distance ring variables are also interacted with the distance to the industrial heritage site, $D$ (in meters), which allows for a spatial component that measures the distance

\footnotetext{
5 This implicitly assumes that the unobserved changes in neighborhood characteristics in the target and control area are similar. The alternative specification and the use of matching estimators to find the correct control area make this assumption more reasonable. ${ }^{6}$ It is likely that the anticipation effect started before the start of the transformation project. However, given our data, it is difficult to account for earlier anticipation effects. In this way, we let the data decide whether there are anticipation effects when the transformation is in progress looking at the significance of the estimators.
} 
decay of the external effects. We also include the quadratic form of the distance variable to see whether the distance decay is linear, concave or convex.

\subsection{Alternative specification}

There are a few drawbacks of the baseline specification. Without doing sensitivity analysis it is not clear what the treatment radius is for each industrial heritage site. Also, the distance decay is assumed to be linear, concave or convex over the distance to the industrial heritage site. To address these drawbacks, we extend the baseline specification by defining the treatment radius $r$ somewhat differently. We propose to draw 100 meter rings within the treatment radius $r$, which allows us to estimate several treatment coefficients depending on whether the observed sold house is within a certain distance ring from the redeveloped industrial heritage site. In other words, we draw 100 meter rings around the redeveloped industrial heritage site where we identify groups of houses that are sold in each distance ring given a certain treatment radius $r_{\max }$, which can be set according to the findings of the baseline specification. This allows us to simply find the reach of the external effect for each transformation project. In addition, it allows for a more flexible specification regarding the distance decay function. The alternative specification is then:

$$
\ln \left(P_{i j t}\right)=\sum_{r=d_{1}-d_{2}}^{r_{\max }} \sum_{s=1}^{S} \alpha_{r s} R_{i t r s}+\sum_{k=1}^{K} \beta_{k} X_{k i}+\gamma_{t} Y_{t}+\pi_{j} N_{j}+\varepsilon_{i t}
$$

where we do not include the distance as a continuous variable but we estimate separate coefficients for different distance rings. The parameters $\alpha_{r s}$ allow for different house price distributions within the treatment radius and should also capture the external effect of the redeveloped industrial heritage site, but somewhat differently than in the baseline model. The number of observations allows us to use rings of 100 meters. This implies that we get a coefficient, $\alpha_{r s}$, for each distance ring (100m-200m, 200m-300m, et cetera). ${ }^{7}$ This specification offers a flexible way to relax the assumption on the homogeneity of the external effect within the treatment radius. However, we do assume that the unobserved (time-variant) forces that could influence house prices between each ring are homogenous. This assumption is more likely to hold with the use of distance rings than when one uses neighborhoods to identify the target and control areas. ${ }^{8}$ The other parameters control for observed structural characteristics, year effects, and unobserved time-invariant neighborhood characteristics.

\footnotetext{
${ }^{7}$ See the technical appendix for a graphical overview.

${ }^{8}$ The omitted variable bias caused by other unobserved investments or developments is likely to be less problematic using small distance rings compared to using neighborhoods. This is evident when the unobserved investments or developments are targeted at neighborhoods. Hence, using distance rings (partially) overcomes this problem.
} 


\subsection{Target groups}

The target group is defined as those sold houses that received treatment. A sold house receives treatment if the house is within a certain distance (treatment radius) to the redeveloped industrial heritage site and the transaction year is equal or larger than the transformation year.

Let us first discuss the distance. Since it is ex ante difficult to predict the extent of the external effect - if there is any - we define different areas that are targeted. We start with a treatment radius of $1 \mathrm{~km}$. This assures us that there are no sold properties in the control group that receive treatment. As described before, we use two different specifications to investigate the decay of the external effect over space. First, we use distance as a continuous variable in a setting that is closely related to Schwartz et al. (2006). Second, we use different distance rings within the treatment radius to allow more flexibility. Using this strategy we let the data and our model specifications tell us what the reach of the external effect is and its distance decay. Because we estimate these regressions separately for each case, it is possible that the reach and decay of the treatment effect is different.

It is also not always easy to identify the exact transformation year for most of the industrial heritage sites. The transformation process of industrial heritage sites is often phased and different parts of the redevelopment process finish at different moments in time. For our cases, we investigated the transformation period carefully and chose to treat the moment that the redevelopment of the real estate was finished as the year of transformation and account for some of the anticipation effects by using the moment that the redevelopment started as the start of the transformation.

This already covers part of the problem that is often present in these types of research. Namely, households should be able to anticipate to changes in their neighborhood. In a world where there is perfect information and no mobility costs, households are likely to anticipate the upcoming changes to the industrial heritage sites. What happens is that if households know the neighborhood will improve in the near future, the neighborhood will possibly become more attractive and, therefore, house prices will increase even before the redevelopment takes place. However, the housing market is more rigid and households often do not have perfect information. Also, debate on these transformation projects by local governments can be complex and often take a lot of time. For example, the idea to transform the Westergasfabriek started decades ago but the transformation eventually started in $2000 .{ }^{9}$ In this paper we cannot check for all anticipation effects due to data limitations but we do account for the anticipation effect between the start and finish of the transformation project. If there are some anticipation effects before the start of the transformation period, this will likely cause an underestimate of the measured external effects of the BEFORE variable.

\footnotetext{
${ }^{9}$ See the technical appendix for more information on the redevelopment projects that we cover in this paper.
} 


\subsection{Control groups}

In the literature, it is standard practice to use the outer rings as control areas (see, for example, Ahlfeldt et al. (2013a), Helmers \& Overman (2013), and Schwartz et al. (2006)). This is what we do initially. We start by including sold houses within 2000 meter of the redeveloped industrial heritage site. As described above, the initial target group are those houses that are within 1000 meter of the redeveloped industrial heritage site and are sold after the completion of the transformation (AFTER). By including additional variables (BEFORE and BETWEEN, specified above), the control group is then defined as those sold houses that are between 1000 and 2000 meter of the redeveloped industrial heritage site. ${ }^{10}$ This methodology does imply that the outer rings, or the control area, should be identical to the target area to produce consistent estimates of the external effect. It can be argued that this is an implausible assumption because the researcher is often not able to fully capture the differences between the control and target group.

Since the target area is not randomly assigned we could, as an alternative, use a matching procedure to match similar neighborhoods to our target area and define those matched neighborhoods as control areas. Using these matching estimators to define a specific control group that is closely identical to the target group is becoming more popular in the economic literature (e.g. Ahlfeldt et al., 2013b; Koster \& Van Ommeren, 2012; McMillen \& McDonald, 2002; Muehlenbachs et al., 2013). ${ }^{11}$

We use the method of Rosenbaum \& Rubin (1983) in a similar fashion as in Koster \& Van Ommeren (2012). The idea is that neighborhoods prior to the transformation have similar characteristics and therefore have similar propensity scores, which are estimated by a probit (or logit) regression. We include many neighborhood characteristics, such as population density, share of foreign migrants, distance to the nearest train station, et cetera. This method enables us to match neighborhoods by minimizing the difference in propensity scores between the target and control neighborhoods. Potential control neighborhoods are located between $1 \mathrm{~km}$ and $10 \mathrm{~km}$ from the redeveloped industrial heritage site. These matched pairs are then more-or-less identical to each other, except for the treatment that the target area has had due to the redevelopment of the industrial heritage.

\footnotetext{
10 We also excluded some distance rings between the target and control group to minimize spillover effects between the two groups. The results show negligible changes.

${ }^{11}$ For more details on matching techniques, see Abadie \& Imbens (2002; 2006; 2011) and Abott \& Klaiber (2011).
} 
We use property transaction data provided by the Dutch Association of Real Estate Agents (NVM). This dataset contains a large share (between 60 and 75\%) of owner-occupied house transactions in the Netherlands between 1985 and 2011. We have information on the exact location of those houses, the transaction price, and a whole list of structural characteristics of the sold houses, such as floor area (in square meters), the number of rooms, maintenance status, type of house, parking, monument status, year of construction, et cetera. We start with selecting these houses that are within $2 \mathrm{~km}$ of each of the transformation project and sold between 1995 and 2011. For each sold house we calculate the distance to the industrial heritage site. In the technical appendix we show for each case the location of each sold house and how many observations we have per 100 meter before and after the transformation year.

We also collect spatial data to control for time-variant local characteristics. We use the location of listed built monuments, provided by the RCE Netherlands Cultural Heritage Agency, to calculate the number of listed build monuments per 50 meter radius for each sold house. We include this variable in our estimation to account for the special (historic) atmosphere that is provided by a bundle of listed built monuments. In addition, we use some information of the neighborhood. In the Netherlands, neighborhoods have, on average, around 1500 inhabitants. We include the share of foreign migrants and population density which are provided by Statistics Netherlands. ABF Research has provided us with data on the distance to the nearest intercity station and nearest highway ramp for each neighborhood. The distance to the nearest 100000 jobs is provided by PBL Netherlands Environmental Assessment Agency.

Table 2 shows a summary of the case-specific descriptive statistics for most variables that we include in our estimation procedure. It is clear from these figures that the study areas are very different from one another. The area around the Westergasfabriek (Amsterdam), Villa Augustus (Dordrecht) and the Zaanse Chocoladefabriek (Zaanstad) are typically more urban than the area around the DRU Cultuurfabriek (Ulft) and Wooncomplex Tricot (Winterswijk). Around the Westergasfabriek, more than $95 \%$ of the sold properties are apartments which are on average smaller and have fewer rooms compared to the other case studies, where the share of apartments is substantially smaller.

Figure 1 plots mean log transaction prices between 1996 and 2011 for each of the 5 cases without controlling for housing characteristics. The sample includes sold houses within $2 \mathrm{~km}$ of the industrial heritage sites: Westergasfabriek (WG), Villa Augustus (VA), Zaanse Chocoladefabriek (ZC), DRU Cultuurfabriek (DC), and Wooncomplex Tricot (WT). This graph shows similar house price trends: (1) a strong rise in the 90s that continues after the millennium, and (2) a weak decrease after the recession started at the completion of 2007. 


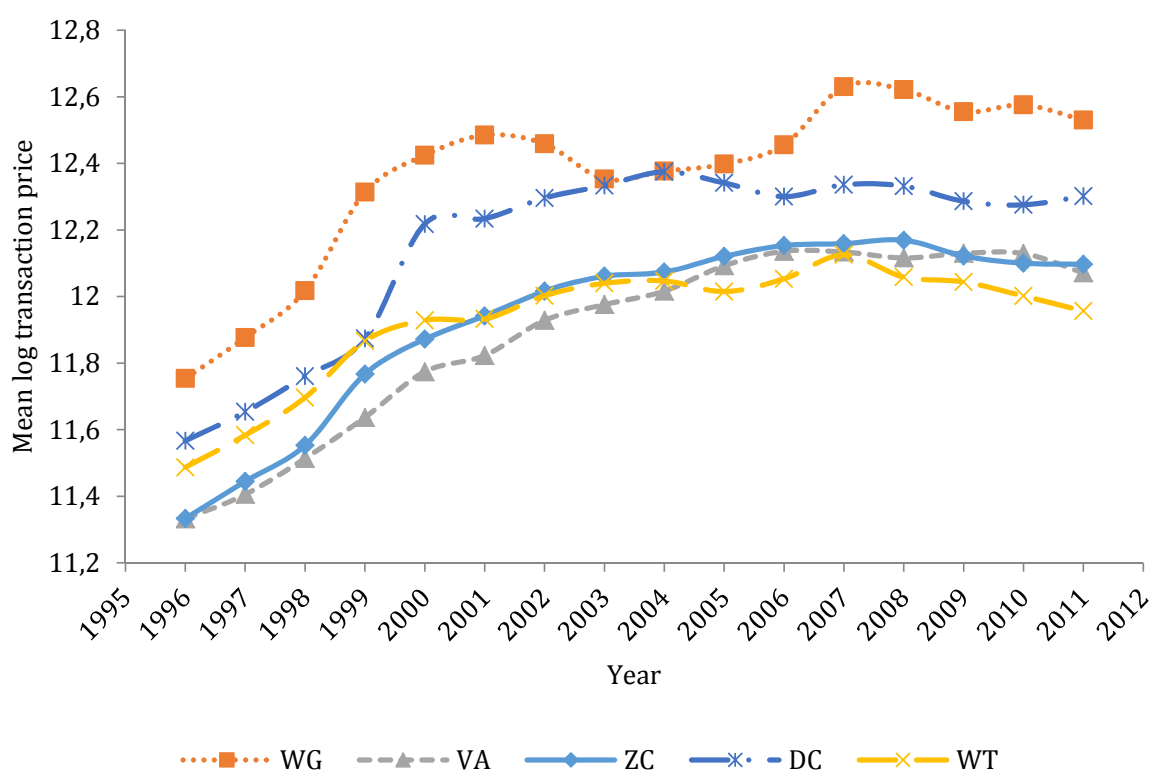

Source: NVM (1996-2011), own calculations.

Figure 1. Average transaction prices of sold houses within $2 \mathrm{~km}$ 
Table 2. Summary of the descriptive statistics by case

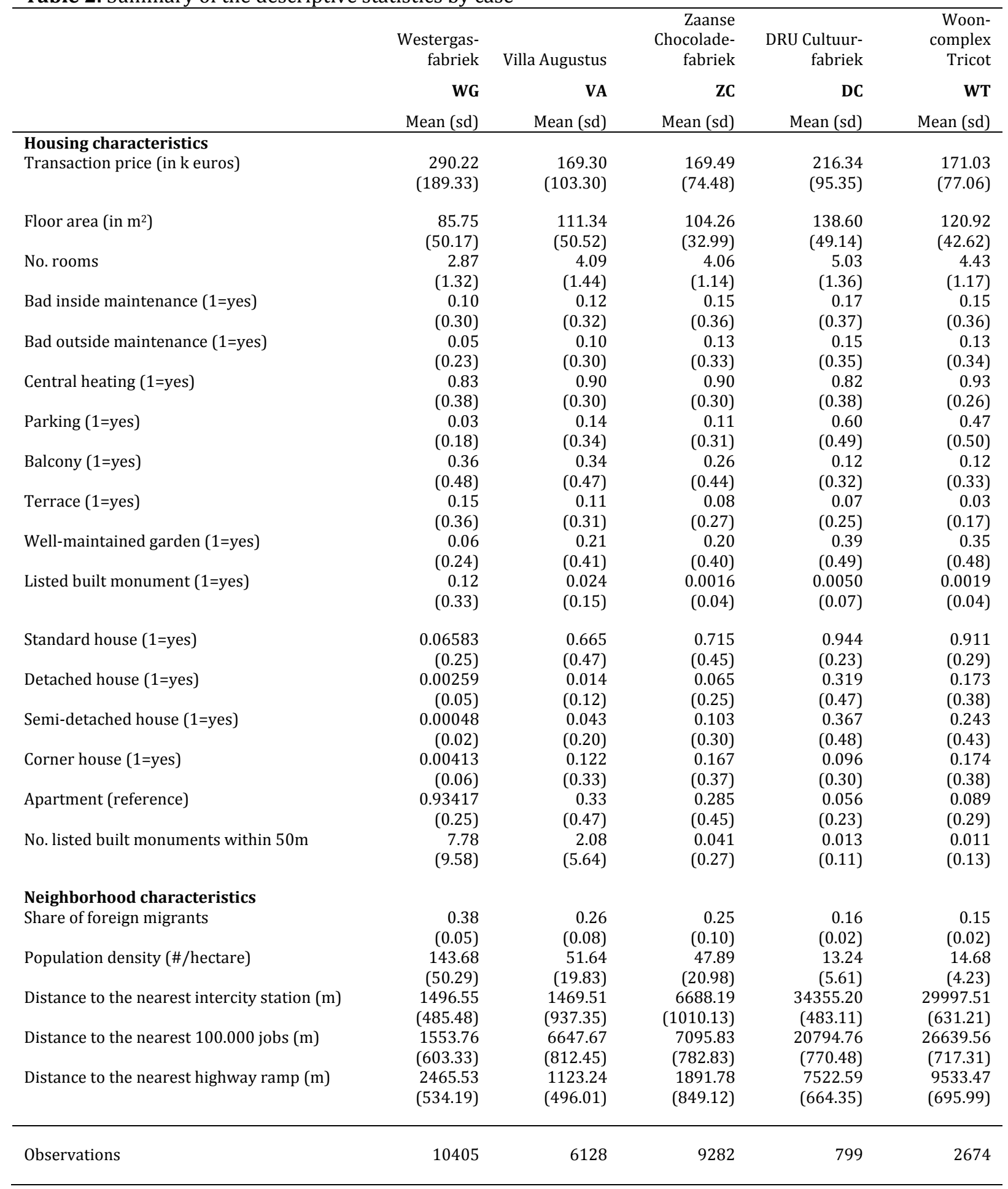

Note: For the summary statistics we only include sold houses that are within $2 \mathrm{~km}$ of the redeveloped industrial heritage site. 
In this section we report the estimation results of the quasi-experimental hedonic price model. We investigate whether there are external house price effects of redeveloping industrial heritage sites on nearby houses and the magnitude of these external effects over time and space. We report the results of the baseline and alternative specification where the target area is defined as those houses that are sold within the first 1000 meter from the redeveloped industrial heritage site and are sold after the completion of the transformation. The control area is defined as those houses that are sold between 1000 and 2000 meter. Results of the alternative specification will then determine the treatment radius for the final estimation. We use the new treatment radius for each case in combination with propensity score matching. The propensity score matching method is used to find control neighborhoods that are similar to the target area. The final estimation uses the baseline specification with adjusted treatment radius for each case and only includes the matched target-control pairs.

\subsection{Results of the baseline specification}

Table 3 reports the key coefficients and standard errors for the baseline model for the 5 cases: Westergasfabriek (WG), Villa Augustus (VA), Zaanse Chocoladefabriek (ZC), DRU Cultuurfabriek (DC), and Wooncomplex Tricot (WT). The coefficients can be interpret as percentage changes. The number of observations varies between 799 for DC and 10405 for the WG. For each case, the adjusted $\mathrm{R}^{2}$ is above 0.8 which suggests that the model fit is good with respect to the hedonic price literature, which is a consequence of including time and location fixed effects.

The key variables are BEFORE, BETWEEN, AFTER and TREND variables from Equation (1). The other coefficients of the WG are reported in Table A.1. of Appendix A. It is clear that the heterogeneity between the coefficients for the different cases is large. For this reason we do not pool the data in the first place as we expect these disparities between transformation projects. The coefficients of the BEFORE variable are only negative and significantly different from zero for the WG and ZC. For these cases, prior to the start of the transformation, properties located next to an industrial heritage site $(D=0)$ sold for 9 to $14 \%$ less than properties between 1000 and 2000 meter of the industrial heritage site. This suggests that these former industrial sites are a disamenity for nearby houses, as is in line with the findings of De Groot \& De Vor (2011). Especially, for industrial heritage sites where the soil was heavily contaminated as was the case for the WG. The results show that distance does often matter. In the case of the WG, we find that the negative external effect decreases with $1.8 \%$ for every 100 meter at a $90 \%$ significance level. This means, for example, that if a house located 300 meter from the WG was sold before the start of the transformation project, it would have been sold for $8.4 \%(=(-0.138+(300 * 0.0018)) * 100)$ less than a similar house between 1000 and 2000 meter of the WG. This distance decay effect is 
linear and only significantly different from zero on a $90 \%$ level. In the case of the ZC, the distance decay effect is not linear but decreasingly increasing (concave) per $100 \mathrm{~m}$. The negative external effect decreases around $2.6 \%$ for the first 100 meter $(D=100)$ and decreases less with increasing distance. This means that before the transformation of the $\mathrm{WG}$ and $\mathrm{ZC}$, the industrial site was a disamenity for the surrounding residential area and that this negative external effect decreased over space. It is worthy to note that VA (former water tower), DC (former ironworks), and WT (former textile factory) seem not to be disamenities for their surrounding residential areas before the start of the transformation as we find no negative and significant effects for the BEFORE variable.

The coefficients that capture a part of the anticipation effect of the transformation project, the variable BETWEEN, are only positive and significantly different from zero on a 95\% level for the WG and ZC. This implies that the negative external effects disappeared after the start of these transformation projects. Moreover, the results show that households who bought their properties located next to these transformation projects $(D=0)$ between the start and the completion of the transformation project had to pay around, respectively, $7 \%$ and $6 \%$ extra for their house compared to similar houses between 1000 and 2000 meter of the transformation project. The distance decay effect is only found for the WG. It is linear and the price effect is $2.3 \%$ per 100 meter. These results suggest that there were positive anticipation effects within $300 \mathrm{~m}$ from the WG between the start and the completion of the transformation project.

Next we discuss the presence of external effects within the treatment radius after the transformation project is finished. The coefficients of the variable AFTER capture this effect on house prices. This variable is only positive and on significant for the WG and WT. The results for the WG and WT show that properties located next to the former industrial heritage site are, respectively, $11.6 \%$ and $18.4 \%$ more worth than comparable properties located between 1000 and 2000 meter from the former industrial heritage site. Surprisingly, for both of the cases there does not seem to be a distance decay effect. This means that all properties within 1000 meters from the WG and WT after the completion of the transformation were sold for an extra $11.6 \%$ and $18.4 \%$, respectively, compared to similar houses between 1000 and 2000 meter from the WG and WT. These numbers are very substantial compared to the other transformation projects where we do not find any positive external effects after the completion of the transformation project. For the $\mathrm{ZC}$, we even see the positive anticipation effect disappear after the transformation. 
Table 3. Regression results of the baseline specification

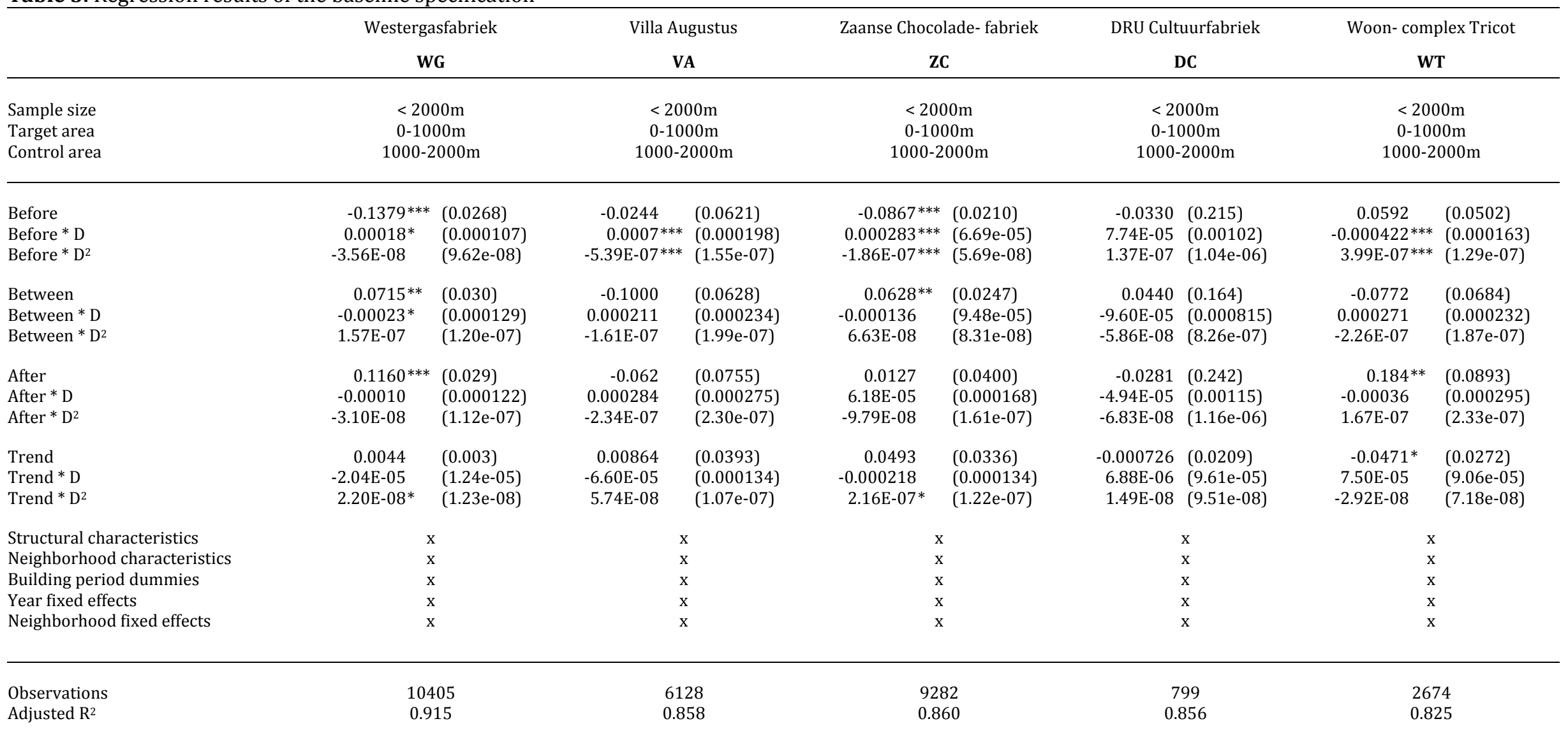

Note: Dependent variable is $\ln$ (transaction price). The coefficients of the control variables for the WG can be found in Tabel A.1 of Appendix A. The other coefficients can be obtained from the author. Robust standard errors are reported between parentheses.

${ }^{*} \mathrm{p}<0.10 ; * * \mathrm{p}<0.05 ; * * * \mathrm{p}<0.01$. 
In our view, the main difference why we find positive external effects after the transformation for the WG and WT is the substantial investments on the redevelopment, and that these investments were predominantly made in the exterior of the industrial heritage sites. The substantial investments made in the WG and WT seemed to significantly improve the quality of the surrounding residential area where the other transformation projects apparently did not. The redevelopment did however make the negative external effect of residing close to an industrial heritage site disappear.

The TREND variable captures whether the external effects after the completion of the transformation project changed over time. It may be the case that households were too optimistic and overestimated the external effects and that house prices increased above the equilibrium prices (a form of 'overshooting' in the housing market) or, vice versa, that the redeveloped industrial heritage site became more attractive after a few years (a form of 'undershooting' in the housing market). Table 3 reports no significant coefficients at the 95\% level. Thus there is no clear evidence based on our selected cases that there is a trend effect after the transformation project is finished.

\subsection{Results of the alternative specification}

The alternative specification allows us to be more flexible on the functional form of the external effect within the 1000 meter treatment radius. We draw 100 meter distance rings within the treatment radius $(0 \mathrm{~m}-100 \mathrm{~m}, 100 \mathrm{~m}-200 \mathrm{~m}, 200 \mathrm{~m}-300 \mathrm{~m}$, et cetera). Moreover, we can estimate the reach of the external effects which are likely to be different for each transformation project. Table 4 reports only the key coefficients of the AFTER variable, our main variable of interest, and its standard errors for the alternative specification. The other coefficients for the WG are reported in Table A.2. of Appendix A.

For the WG there are many positive and significant coefficients. This suggests that there are positive external effects on house prices present after the transformation of the WG. It seems that the extent of the external effect is around 600 meter for the WG. The size of the effect is between $+6 \%$ and $+14 \%$ in terms of house prices. For the other transformation projects we do not find clear evidence showing external effects on house prices after the transformation.

The distance decay of the external effect does not seem to be straightforward if we look at the WG results. The coefficients suggest that there is a relatively large effect within 100 meter of the WG, but decreases in halve after 100 meter. The coefficients stay around the same between 100 and 600 meter of the WG, although one of the coefficients is not significant different from zero. Also, most of the WG coefficients are not significantly different from each other.

The disadvantage of this specification is obviously that you split the number of observation of the treatment area. In the baseline specification, we allow for a maximum of three coefficients 
(one main variable and two interaction variables with the distance to the industrial heritage site) whereas in the alternative specification we allow for 10 coefficients. Also, some industrial sites only have a limited amount of houses within the first 100 meters of the site. More information on the number of observations for each site can be found in the technical appendix. Therefore, we only use this specification to find the reach of the external effect.

Table 4. Regression results of the alternative specification

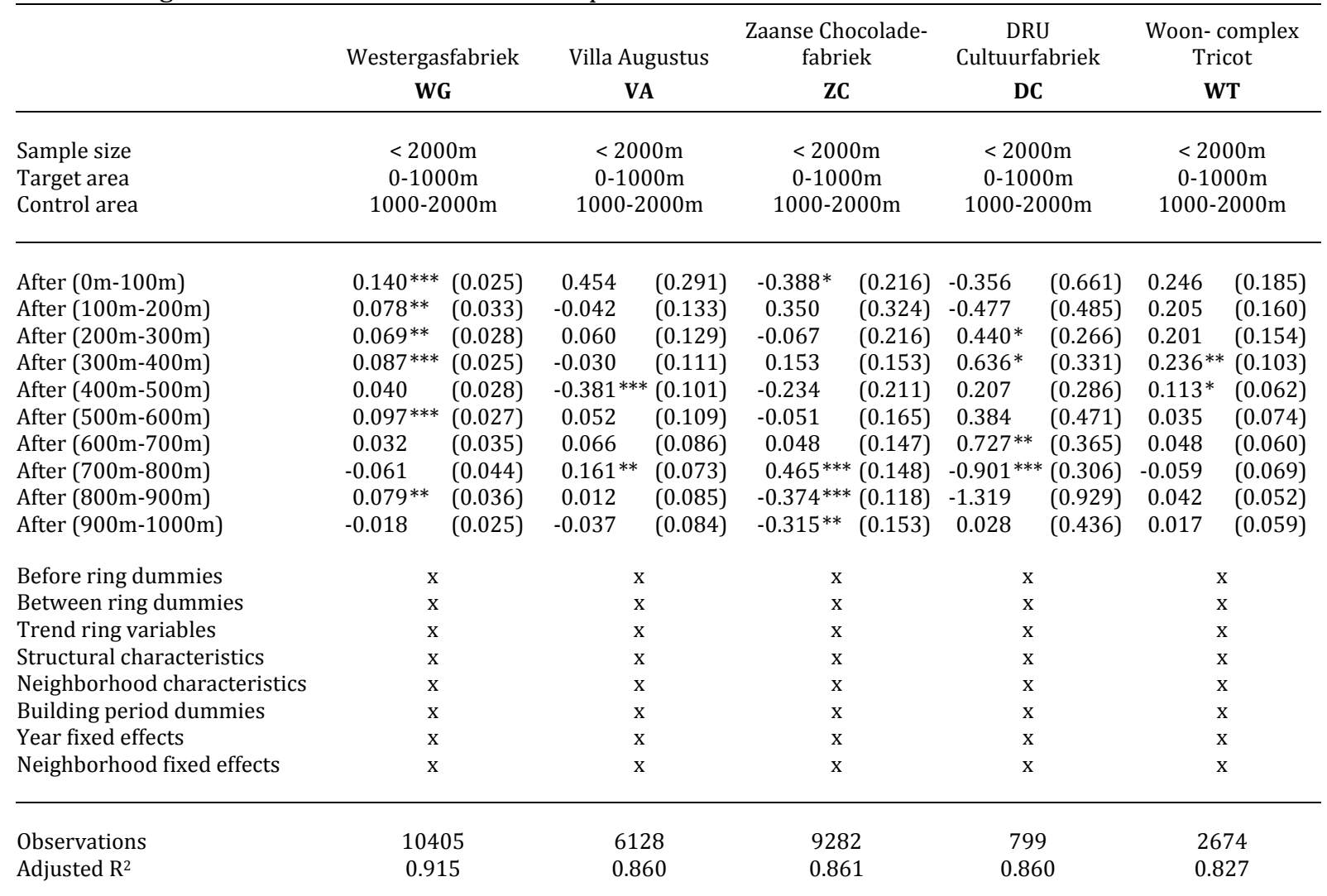

Note: Dependent variable is ln(transaction price). The coefficients of the other variables for the WG can be found in Tabel A.2 of Appendix A. The other coefficients can be obtained from the author. Robust standard errors are reported between parentheses. $* \mathrm{p}<0.10 ; * * \mathrm{p}<0.05 ; * * * \mathrm{p}<0.01$

\subsection{Results using the propensity score matching}

Based on the alternative specification in Section 5.2, we define a specific treatment radius for each redeveloped industrial heritage site. For the sites that seem to not have external effects on house prices caused by the transformation, we set the treatment radius at 400 meter. In addition, we specify a control area based on the popular propensity score matching method. This matching method uses quantitative methods to find control areas that are as similar as possible to the treatment area before the transformation, given many neighborhood characteristics. For the WG, the control area consists of specific neighborhoods in and around the city center of 
Amsterdam but is restricted to be between 1 and 10 kilometer from the WG. For the other cases, the control areas are neighborhoods in other municipalities but restricted to be between 2 and 10 kilometer from the industrial heritage site. This ensures that it is impossible that the redevelopment of the industrial heritage site has had any impact on the control area. This is our preferred model specification.

Table 5 reports the results of the baseline specification that takes into account different treatment areas for each case based on the previous estimation results and different control areas based on propensity score matching. The other coefficients for the WG are reported in Table A.3. of Appendix A. The BEFORE variable shows some significant negative coefficients for the WG and VA. This suggests that the industrial heritage sites, WG and VA, were a disamenity for the surrounding houses before the redevelopment. The price effect is $-36 \%$ and $-32 \%$, respectively, compared to the control neighborhood(s) that are determined by propensity score methods. For the WG the distance decay effect is linear. The negative external effect decreases with $4 \%$ for every 100 meter. In the case of VA, the distance decay effect is not linear but decreasingly increasing per 100 meter. The negative external effect decreases around $3 \%$ for the first 100 meter $(D=100)$ and decreases less with increasing distance. For the DC and WT we do not find any evidence that the industrial heritage site had any impact on house prices before the transformation compared to the control area.

Again, we find that the negative external effects disappear after the start of the transformation project. We only find positive anticipation effects for the WG if we look at the results of the BETWEEN variable. This anticipation effect is significant for houses within $600 \mathrm{~m}$ from the WG. These houses are sold for around $8 \%$ higher between the start and the completion of the transformation compared to the control area. For the other transformation projects, we find no significant anticipation effects within 400 meters.

Our main variable of interest, AFTER, is only significant for the WG. This is in line with previous results of the other specifications. The external effect after the redevelopment of the WG is highly significant within 600 meters and is $20 \%(D=0)$ compared to the control area. This positive external effect is high, however, the effect decreases with distance. For every 100 meter the house is located from the WG the external effect decreases with $5 \%$ on a $90 \%$ significance level. This suggests that the reach of the external effect for WG is 400 meters using this specification.

The TREND variable seems not significant for each of the transformation projects. For WG, this means that the external effect after the redevelopment did not decrease over time. This suggests that the positive external effects of the WG are persistent over time. 
Table 5. Regression results of the baseline specification using propensity score matching

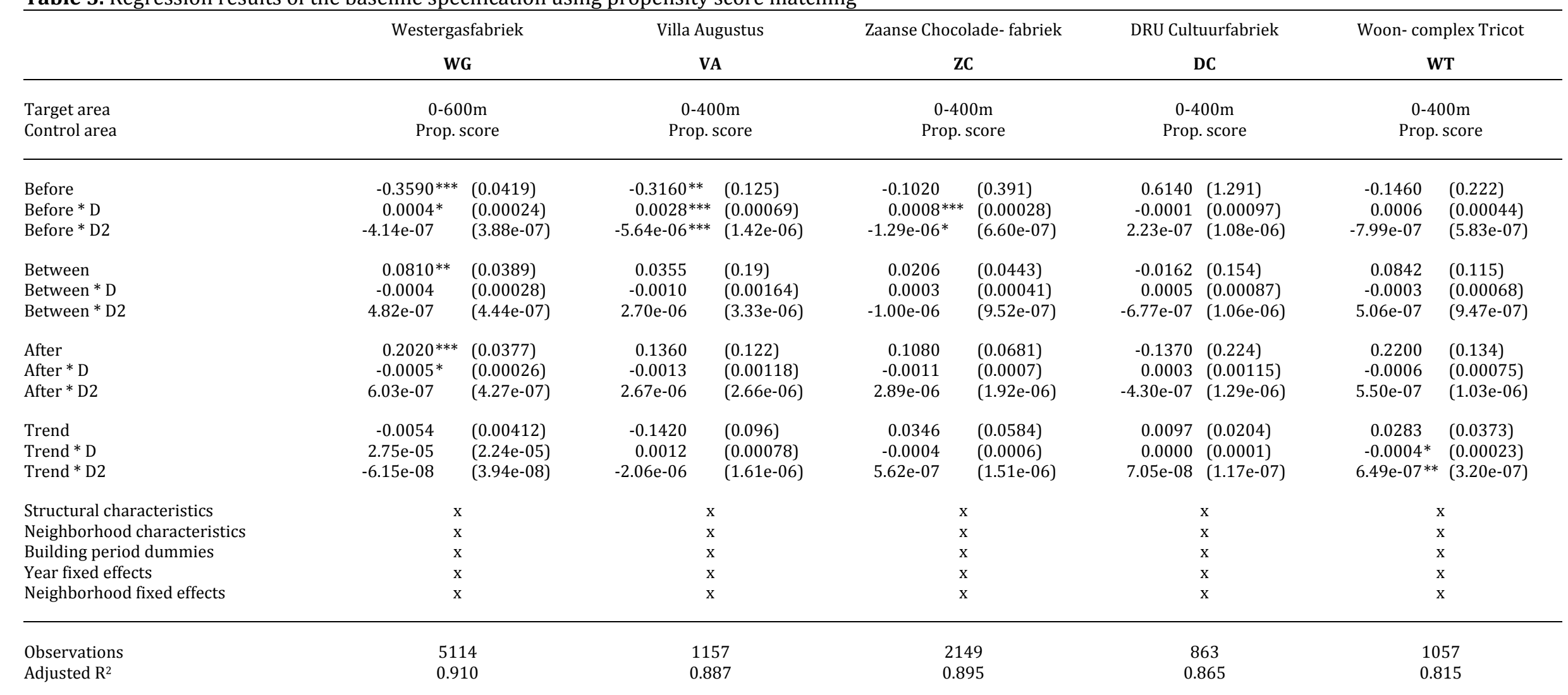

Note: Dependent variable is $\ln ($ transaction price). The coefficients of the control variables for the WG can be found in Tabel A.3 of Appendix A. The other coefficients can be obtained from the author. Robust standard errors are reported between parentheses.

${ }^{*} \mathrm{p}<0.10 ; * * \mathrm{p}<0.05 ; * * * \mathrm{p}<0.01$ 
In this paper we investigate the presence of positive external effects on house prices after the redevelopment of several industrial heritage sites in the Netherlands. The cases we consider are former industrial heritage sites with a cultural-historic background that lost their original function: Westergasfabriek (a former gasfactory in Amsterdam), Villa Augustus (a former water tower in Dordrecht, located east of Rotterdam), Zaanse Chocoladefabriek (a former chocolate factory in Zaanstad, located north of Amsterdam), DRU Cultuurfabriek (a former iron foundry in Ulft, located in the eastern part of the Netherlands) and Wooncomplex Tricot (a former textile factory in Winterswijk, also located in the eastern part of the Netherlands). Local governments independently decided that the cultural-historic aspects of these sites should be preserved and decided to redevelop these sites. However, the location, size of the site, size of the investment and whether the investment was predominantly made in the interior or exterior of the transformation project is substantially different for each site.

We use a quasi-experimental hedonic price methodology that compares quality-adjusted house prices of sold houses within a certain treatment radius before the start of the transformation project, between the start and completion, and after the completion of the transformation project and compared them to a predefined control area. We control for many housing and neighborhood characteristics. We pay special attention to defining the treatment and control area. The treatment area is defined by using a flexible 'alternative' specification using 100 meter distance rings that allows us to test the reach of the external effects on house prices. The control area is first defined as the most outer ring (sold houses between 1000 meter and 2000 meter of the redeveloped industrial heritage site) but we also use a matching estimator to define a control area that is as similar as possible to the treatment area given many local characteristics. Although our methodology might not fully solve the omitted variable bias caused by unobserved investments or developments, which may cause inconsistent estimators, but it tries to minimize this problem. The possible overestimation of the results does, however, not have any impact on the main conclusion of this paper: Positive external effects on house prices do not necessarily arise after redeveloping industrial heritage sites.

We find that the results on external effects between our cases are quite heterogeneous. It is often assumed that industrial sites generate negative external effects on nearby residential properties. We show that this is not necessarily true. However, if we find negative external effects before the redevelopment of an industrial heritage site, they disappear at the start of the redevelopment. These negative external effects can be substantial but they decrease over space and they seem to be dependent on the size and type of industrial site. Prices of sold houses close to the Westergasfabriek were between $14 \%$ and 36\% lower than the control area before the transformation. These negative external effects decrease quickly over space. For Villa Augustus 
and the Zaanse Chocoladefabriek, we only find some evidence of negative external effects before the transformation and these seem to disappear at the start of the transformation.

These results suggest that there are anticipation effects. This implies that house prices already (partly) adjust before the completion of the transformation. For the Westergasfabriek we even find that positive external effects are partly anticipated. For the other cases, we do not observe this.

If the investments in the redevelopment of industrial heritage sites are substantial and predominantly focused at the exterior, this may lead to an increase in the quality of the neighborhood. Hence, positive external effects may arise after the redevelopment. Only for the Westergasfabriek we find persistent positive external effects after the redevelopment. We find positive external effects on house prices between $11 \%$ and $20 \%$ around the Westergasfabriek after the redevelopment in 2003. There is still to discuss whether these positive external effects are caused by the redevelopment or other (unobserved) investments or developments in the surrounding residential area.

This paper has clear policy implications. Our results show that it is not self-evident that the renovation of an abandoned industrial site has a substantial impact on the quality of the neighborhood. This paper shows that significant external effects on house prices do not necessarily arise after industrial sites are redeveloped. We argue that the details of the transformation and the location are important factors for the generation of external effects. The investment needs to be substantial and predominantly made on the exterior of the industrial heritage site (e.g. green open space, new attractive buildings, and (cultural) activities). This suggests that policy makers need to be cautious when copying successful transformation projects. There seems to be no 'one-size-fits-all' policy for redeveloping industrial sites.

\section{Acknowledgements}

The authors gratefully acknowledge Platform 31, the University of Groningen, and VU University for their financial support. We thank NVM, ABF Research and Statistics Netherlands for providing us with excellent data. We would also like to thank Henri Overman, Marc Francke and the participants in the Urban Future Lectures, ERES and AREUEA conferences for useful comments on previous drafts. 


\section{References}

Abadie, A. \& Imbens, G. (2002). Simple and Bias-Corrected Matching Estimators for Average Treatment Effects, NBER Working Paper 283.

Abadie, A. \& Imbens, G. (2006). Large Sample Properties of Matching Estimators for Average Treatment Effects, Econometrica, 74(1), 235-267.

Abadie, A. \& Imbens, G. (2011). Bias-Corrected Matching Estimators for Average Treatment Effects, Journal of Business and Economic Statistics, 29(1), 1-11.

Abott, J.K. \& Klaiber, H.A. (2013). The Value of Water as an Urban Club Good: A Matching Approach to Community-Provided Lakes, Journal of Environmental Economics and Management, 65(2), 208-224.

Ahlfeldt, G.M. (2011). Blessing or Curse? Appreciation, Amenities and Resistance to Urban Renewal, Regional Science and Urban Economics, 41(1), 32-45.

Ahlfeldt, G.M., Möller, K., Waights, S., \& Wendland, N. (2013a). Game of Zones: The Economics of Conservation Areas, Working paper.

Ahlfeldt, G.M., Maennig, W., \& Richter, F.J. (2013b). Urban Renewal after the Berlin Wall, Working paper.

Brooks, L., \& Phillips, J. (2007). Inside the Gift Horse's Mouth: City Spending, Political Institutions and the Community Development Block Grant Program, McGill University Working Papers.

Brueckner, J.K., \& Rosenthal, S.S. (2009). Gentrification and Neighborhood Housing Cycles: Will America's Future Downtowns Be Rich?, The Review of Economics and Statistics, 91(4), 725-743.

Brueckner, J.K., Thisse, J.F., \& Zenou, Y. (1999). Why is Central Paris Rich and Downtown Detroit Poor? An Amenity-Based Theory, European Economic Review, 43(1), 91-107.

Carlino, G.A., \& Coulson, N.E. (2004). Compensating Differentials and the Social Benefits of the NFL, Journal of Urban Economics, 56(1), 25-50.

Carlino, G.A., \& Saiz, A. (2008). City Beautiful, IZA Discussion Paper No. 3778.

Chen, Y., \& Rosenthal, S.S. (2008). Local Amenities and Life-Cycle Migration: Do People Move for Jobs or Fun? Journal of Urban Economics, 64(3), 519-537.

Cheshire, P., \& Sheppard, S. (1995). On the Price of Land and the Value of Amenities, Economica, 62(246), 247-267.

Coulson, N.E., \& Bond, E.W. (1990). A Hedonic Approach to Residential Succession, The Review of Economics and Statistics, 72(3), 433-444.

CPB \& PBL (2010). Evaluatie beoordelingen Nota Ruimteprojecten. Den Haag: Centraal Planbureau en Planbureau voor de Leefomgeving.

De Groot, H.L.F, \& De Vor, F. (2011). The Impact of Industrial Sites on Residential Property Values: A Hedonic Pricing Analysis from the Netherlands, Regional Studies, 45(5), 609-623.

Florida, R. (2002). The Rise of the Creative Class. Basic Books, New York.

Glaeser, E.L., Kolko, J., \& Saiz, A. (2001). Consumer City, Journal of Economic Geography, 1(1), 27-50.

Harding, J.P., Rosenthal, S.S., \& Sirmans, C.F. (2007). Depreciation of Housing Capital, Maintenance, and House Price Inflation: Estimates from a Repeat Sales Model, Journal of Urban Economics, 61(2), 193217.

Helmers, C., \& Overman, H. (2012). My Precious! The Location and Diffusion of Scientific Research: Evidence from the Synchrotron Diamond Light Source, Working paper.

Ioannides, Y.M. (2003). Interactive Property Valuations, Journal of Urban Economics, 53(1), 145-170.

Jacobs, J. (1961). The Death and Life of Great American Cities. New York: Random House.

Koster, H.R.A., \& Van Ommeren, J.N. (2013). Spatial Externalities and Place-Based Policies: Evidence from the Netherlands, Working paper. 
Linn, J. (2013). The Effect of Voluntary Brownfields Programs on Nearby Property Values: Evidence from Illinois, Journal of Urban Economics, 78(1), 1-8.

Maliene, V., Wignall, L., \& Malys, N. (2012). Brownfield Regeneration: Waterfront Site Developments in Liverpool and Cologne, Journal of Environmental Engineering and Landscape Management, 20(1), 5-16.

McMillen, D.P., \& McDonald, J.F. (2002). Land Values in a Newly Zoned City, The Review of Economics and Statistics, 84(1), 62-72.

Muehlenbachs, L., Spiller E., \& Timmins, C. (2013). The Housing Market Impacts of Shale Gas Development, NBER Working paper No. 19796.

Rosen, S. (1974). Hedonic Prices and Implicit Markets: Product Differentiation in Pure Competition, Journal of Political Economy, 82(1), 34-55.

Rosenbaum, P.R., \& Rubin, D.B. (1983). The Central Role of the Propensity Score in Observational Studies for Causal Effects, Biometrika, 70(1), 41-55.

Rosenthal, S.S. (2008). Old Homes, Externalities, and Poor Neighborhoods. A Model of Urban Decline and Renewal, Journal of Urban Economics, 63(3), 816-840.

Rossi-Hansberg, E., Sarte, P.D., \& Owens III, R. (2010). Housing Externalities, Journal of Political Economy, 118(3), 485-535.

SBR \& Aedes (2010). Juweeltjes van herbestemming, 17 parels in de stad. Stichting Bouw Research, Rotterdam, en Aedes, Den Haag.

Schwartz, A.E., Ellen, I.G., Voicu, I., \& Schill, M.H. (2006). The Effects of Place-Based Subsidized Housing, Regional Science and Urban Economics, 36(6), 679-707.

Smith, B.C. (2004). Economic Depreciation of Residential Real Estate: Microlevel Space and Time Analysis. Real Estate Economics, 32(1), 161-180. 


\section{Appendix A. Regression results from the omitted variables in the paper (for WG only)}

Table A.1 Table 3 continued: Results from the other variables (WG only)

\begin{tabular}{|c|c|c|c|c|}
\hline $\ln ($ floor area in $\mathrm{m} 2$ ) & $0.777^{* * *}$ & $(0.0089)$ & Transaction year 1996 (ref: 2011) & $-1.049 * * *(0.0179)$ \\
\hline Rooms (\#) & $0.023^{* * *}$ & $(0.0028)$ & Transaction year 1997 & $-0.924 * * *(0.0169)$ \\
\hline House (ref: apartment) & -0.010 & $(0.0113)$ & Transaction year 1998 & $-0.747^{* * *}(0.0163)$ \\
\hline Detached house & -0.032 & $(0.0456)$ & Transaction year 1999 & $-0.472 * * *(0.0162)$ \\
\hline Semi-detached house & 0.093 & $(0.0795)$ & Transaction year 2000 & $-0.297^{* * *}(0.0147)$ \\
\hline Corner house & 0.053 & $(0.0370)$ & Transaction year 2001 & $-0.209 * * *(0.0138)$ \\
\hline Balcony & $0.022^{* * *}$ & $(0.0034)$ & Transaction year 2002 & $-0.227^{* * *}(0.0128)$ \\
\hline Terrace & $0.068^{* * *}$ & $(0.0050)$ & Transaction year 2003 & $-0.300 * * *(0.0133)$ \\
\hline Private parking & $0.136^{* * *}$ & $(0.0104)$ & Transaction year 2004 & $-0.265^{* * *}(0.0122)$ \\
\hline Well-maintained garden & $0.090^{* * *}$ & $(0.0073)$ & Transaction year 2005 & $-0.212 * * *(0.0112)$ \\
\hline Bad maintenance inside & $-0.125^{* * *}$ & $(0.0067)$ & Transaction year 2006 & $-0.117^{* * *}(0.0103)$ \\
\hline Bad maintenance outside & $-0.086^{* * *}$ & $(0.0092)$ & Transaction year 2007 & $(0.0099)$ \\
\hline Central heating & $0.062^{* * *}$ & $(0.0058)$ & Transaction year 2008 & $0.077^{* * *}(0.0091)$ \\
\hline Listed built monument status & $0.041^{* * *}$ & $(0.0062)$ & Transaction year 2009 & $-0.008 \quad(0.0088)$ \\
\hline Foreign migrants (\%) & $-1.030 * * *$ & $(0.1440)$ & Transaction year 2010 & $0.020 * *(0.0092)$ \\
\hline $\ln$ (population density) & -0.013 & $(0.0149)$ & & \\
\hline $\ln$ (distance to the nearest 100,000 jobs) & $0.106^{* * *}$ & $(0.0153)$ & Located in neighborhood & $0.089 * * *(0.0103)$ \\
\hline $\ln$ (distance to nearest intercity station) & $0.034 * * *$ & $(0.0092)$ & Located in neighborhood & $0.207 * * *(0.0140)$ \\
\hline Listed built monuments in a $50 \mathrm{~m}$ radius (\#) & $-0.001^{*}$ & $(0.0004)$ & Located in neighborhood & $0.075^{* * *}(0.0143)$ \\
\hline $\begin{array}{l}\text { Built in period before } 1905 \text { (ref: built in } \\
\text { period after 2000) }\end{array}$ & $-0.072^{* * *}$ & $(0.0077)$ & Located in neighborhood & $-0.136^{* * *}(0.0146)$ \\
\hline Built in period $1906-1930$ & $-0.087^{* * *}$ & $(0.0077)$ & Located in neighborhood & $0.027^{* * *}(0.0085)$ \\
\hline Built in period $1931-1944$ & $-0.088^{* * *}$ & $(0.0104)$ & Located in neighborhood & $(0.0115)$ \\
\hline Built in period $1945-1959$ & $-0.056^{* *}$ & $(0.0239)$ & & \\
\hline Built in period $1960-1970$ & $-0.133^{* * *}$ & $(0.0267)$ & Constant & $9.334 * * *(0.1510)$ \\
\hline Built in period $1971-1980$ & $-0.123^{* * *}$ & $(0.0113)$ & & \\
\hline Built in period $1981-1990$ & $-0.109 * * *$ & $(0.0089)$ & & \\
\hline Built in period $1991-2000$ & $-0.030 * * *$ & $(0.0082)$ & Observations & 10,405 \\
\hline Built in unknown period & 0.037 & $(0.0334)$ & Adjusted R2 & 0.915 \\
\hline
\end{tabular}

Note: Results from the other cases can be obtained from the author. Robust standard errors are reported between parentheses. $* \mathrm{p}<0.10 ; * * \mathrm{p}<0.05 ; * * * \mathrm{p}<0.01$ 
Table A.2 Table 4 continued: Results from the other variables (WG only)

\begin{tabular}{|c|c|c|c|}
\hline Before (0m-100m) & $-0.145^{* * *}(0.0228)$ & Foreign migrants $(\%)$ & $-1.005^{* * *}(0.1450)$ \\
\hline Before $(100 \mathrm{~m}-200 \mathrm{~m})$ & $-0.079 * * *(0.0303)$ & $\ln ($ population density) & $(0.0151)$ \\
\hline Before $(200 \mathrm{~m}-300 \mathrm{~m})$ & $-0.071 * * *(0.0267)$ & $\ln ($ distance to the nearest 100,000 jobs) & $0.110 * * *(0.0154)$ \\
\hline Before $(300 \mathrm{~m}-400 \mathrm{~m})$ & $-0.109 * * *(0.0228)$ & $\ln ($ distance to nearest intercity station) & $-0.072 * * *(0.0078)$ \\
\hline Before $(400 \mathrm{~m}-500 \mathrm{~m})$ & $(0.0265)$ & $\begin{array}{l}\text { Listed built monuments in a } 50 \mathrm{~m} \text { radius } \\
(\#)\end{array}$ & $-0.087 * * *(0.0078)$ \\
\hline Before $(500 \mathrm{~m}-600 \mathrm{~m})$ & $-0.080 * * *(0.0235)$ & & \\
\hline Before $(600 \mathrm{~m}-700 \mathrm{~m})$ & $(0.0312)$ & $\begin{array}{l}\text { Built in period before } 1905 \text { (ref: built in } \\
\text { period after 2000) }\end{array}$ & $-0.087 * * *(0.0105)$ \\
\hline Before $(700 \mathrm{~m}-800 \mathrm{~m})$ & $(0.0404)$ & Built in period $1906-1930$ & $-0.053 * * \quad(0.0242)$ \\
\hline Before $(800 \mathrm{~m}-900 \mathrm{~m})$ & $(0.0320)$ & Built in period $1931-1944$ & $-0.133 * * *(0.0267)$ \\
\hline \multirow[t]{2}{*}{ Before $(900 \mathrm{~m}-1000 \mathrm{~m})$} & $(0.0189)$ & Built in period $1945-1959$ & $-0.123 * * *(0.0114)$ \\
\hline & & Built in period $1960-1970$ & $-0.108 * * *(0.0090)$ \\
\hline Between $(0 \mathrm{~m}-100 \mathrm{~m})$ & $0.079 * * *(0.0256)$ & Built in period $1971-1980$ & $-0.028 * * *(0.0082)$ \\
\hline Between $(100 \mathrm{~m}-200 \mathrm{~m})$ & $(0.0356)$ & Built in period 1981-1990 & $(0.0342)$ \\
\hline Between $(200 \mathrm{~m}-300 \mathrm{~m})$ & $(0.0295)$ & Built in period 1991-2000 & $-1.049 * * *(0.0180)$ \\
\hline Between $(300 \mathrm{~m}-400 \mathrm{~m})$ & $(0.0280)$ & Built in unknown period & $-0.922 * * *(0.0171)$ \\
\hline Between $(400 \mathrm{~m}-500 \mathrm{~m})$ & $(0.0315)$ & & \\
\hline Between $(500 \mathrm{~m}-600 \mathrm{~m})$ & $(0.0274)$ & Transaction year 1996 (ref: 2011) & $-0.745 * * *(0.0163)$ \\
\hline Between $(600 \mathrm{~m}-700 \mathrm{~m})$ & $(0.0404)$ & Transaction year 1997 & $-0.471 * * *(0.0163)$ \\
\hline Between $(700 \mathrm{~m}-800 \mathrm{~m})$ & $(0.0446)$ & Transaction year 1998 & $-0.296 * * *(0.0147)$ \\
\hline Between $(800 \mathrm{~m}-900 \mathrm{~m})$ & $(0.0360)$ & Transaction year 1999 & $-0.208 * * *(0.0138)$ \\
\hline \multirow[t]{2}{*}{ Between (900m-1000m) } & $(0.0267)$ & Transaction year 2000 & $-0.226 * * *(0.0128)$ \\
\hline & & Transaction year 2001 & $-0.300 * * *(0.0134)$ \\
\hline Trend $(0 \mathrm{~m}-100 \mathrm{~m})$ & $(0.0028)$ & Transaction year 2002 & $-0.263 * * *(0.0122)$ \\
\hline Trend $(100 \mathrm{~m}-200 \mathrm{~m})$ & $(0.0030)$ & Transaction year 2003 & $-0.212 * * *(0.0113)$ \\
\hline Trend $(200 \mathrm{~m}-300 \mathrm{~m})$ & $0.005 * * \quad(0.0026)$ & Transaction year 2004 & $-0.117 * * *(0.0103)$ \\
\hline Trend $(300 \mathrm{~m}-400 \mathrm{~m})$ & $(0.0024)$ & Transaction year 2005 & $0.011 \quad(0.0099)$ \\
\hline Trend $(400 \mathrm{~m}-500 \mathrm{~m})$ & $(0.0024)$ & Transaction year 2006 & $0.077^{* * *}(0.0091)$ \\
\hline Trend (500m-600m) & $(0.0040)$ & Transaction year 2007 & $-0.009 \quad(0.0088)$ \\
\hline Trend $(600 \mathrm{~m}-700 \mathrm{~m})$ & $(0.0036)$ & Transaction year 2008 & $0.021 * * \quad(0.0090)$ \\
\hline Trend $(700 \mathrm{~m}-800 \mathrm{~m})$ & $(0.0036)$ & Transaction year 2009 & $0.090 * * *(0.0104)$ \\
\hline Trend $(800 \mathrm{~m}-900 \mathrm{~m})$ & $(0.0034)$ & Transaction year 2010 & $0.210 * * *(0.0142)$ \\
\hline \multirow[t]{2}{*}{ Trend $(900 \mathrm{~m}-1000 \mathrm{~m})$} & $0.008 * * \quad(0.0035)$ & & \\
\hline & & Located in neighborhood & $0.078 * * *(0.0144)$ \\
\hline $\ln ($ floor area in $\mathrm{m} 2$ ) & $0.776 * * *(0.0089)$ & Located in neighborhood & $-0.140 * * *(0.0145)$ \\
\hline Rooms (\#) & $0.023 * * *(0.0028)$ & Located in neighborhood & $0.023 * * *(0.0085)$ \\
\hline House (ref: apartment) & $(0.0113)$ & Located in neighborhood & $(0.0117)$ \\
\hline Detached house & $(0.0458)$ & Located in neighborhood & $-0.001 * * \quad(0.0003)$ \\
\hline Semi-detached house & $(0.0797)$ & Located in neighborhood & $0.034 * * *(0.0093)$ \\
\hline Corner house & $(0.0365)$ & & \\
\hline Balcony & $0.021 * * *(0.0034)$ & Constant & $9.322 * * *(0.1530)$ \\
\hline Terrace & $0.068 * * *(0.0050)$ & & \\
\hline Private parking & $0.136 * * *(0.0105)$ & & \\
\hline Well-maintained garden & $0.090 * * *(0.0073)$ & & \\
\hline Bad maintenance inside & $-0.126 * * *(0.0067)$ & & \\
\hline Bad maintenance outside & $-0.085 * * *(0.0092)$ & & \\
\hline Central heating & $0.061 * * *(0.0058)$ & Observations & 10,405 \\
\hline Listed built monument status & $0.041 * * *(0.0062)$ & Adjusted R2 & 0.915 \\
\hline
\end{tabular}

Note: Results from the other cases can be obtained from the author. Robust standard errors are reported between parentheses. $* \mathrm{p}<0.10 ;{ }^{* *} \mathrm{p}<0.05 ; * * * \mathrm{p}<0.01$. 
Table A.3 Table 5 continued: Results from the other variables (WG only)

\begin{tabular}{|c|c|c|c|c|c|}
\hline $\ln ($ floor area in $\mathrm{m} 2$ ) & $0.738^{* * *}$ & $(0.0150)$ & Transaction year 1996 (ref: 2011) & $-1.029 * * *$ & $(0.0284)$ \\
\hline Rooms (\#) & $0.027^{* * *}$ & $(0.0045)$ & Transaction year 1997 & $-0.928 * * *$ & $(0.0269)$ \\
\hline House (ref: apartment) & -0.004 & $(0.0206)$ & Transaction year 1998 & $-0.736^{* * *}$ & $(0.0267)$ \\
\hline Detached house & 0.029 & $(0.0751)$ & Transaction year 1999 & $-0.452^{* * *}$ & $(0.0260)$ \\
\hline Semi-detached house & 0.077 & $(0.0497)$ & Transaction year 2000 & $-0.292^{* * *}$ & $(0.0224)$ \\
\hline Corner house & -0.051 & $(0.0387)$ & Transaction year 2001 & $-0.188^{* * *}$ & $(0.0211)$ \\
\hline Balcony & $0.023^{* * *}$ & $(0.0046)$ & Transaction year 2002 & $-0.193^{* * *}$ & $(0.0201)$ \\
\hline Terrace & $0.065^{* * *}$ & $(0.0076)$ & Transaction year 2003 & $-0.317^{* * *}$ & $(0.0238)$ \\
\hline Private parking & $0.138^{* * *}$ & $(0.0154)$ & Transaction year 2004 & $-0.288 * * *$ & $(0.0209)$ \\
\hline Well-maintained garden & $0.085^{* * *}$ & $(0.0109)$ & Transaction year 2005 & $-0.243^{* * *}$ & $(0.0187)$ \\
\hline Bad maintenance inside & $-0.101^{* * *}$ & $(0.0092)$ & Transaction year 2006 & $-0.145^{* * *}$ & $(0.0165)$ \\
\hline Bad maintenance outside & $-0.082 * * *$ & $(0.0110)$ & Transaction year 2007 & -0.017 & $(0.0148)$ \\
\hline Central heating & $0.061^{* * *}$ & $(0.0089)$ & Transaction year 2008 & $0.066^{* * *}$ & $(0.0127)$ \\
\hline Listed built monument status & $0.043^{* * *}$ & $(0.0092)$ & Transaction year 2009 & 0.008 & $(0.0108)$ \\
\hline Foreign migrants (\%) & $-1.304^{* * *}$ & $(0.2130)$ & Transaction year 2010 & $0.022 *$ & $(0.0115)$ \\
\hline $\ln$ (population density) & 0.017 & $(0.0340)$ & & & \\
\hline $\ln$ (distance to the nearest 100,000 jobs) & 0.004 & $(0.0363)$ & Located in neighborhood & 0.031 & $(0.0206)$ \\
\hline $\ln$ (distance to nearest intercity station) & $0.055^{* * *}$ & $(0.0099)$ & Located in neighborhood & $0.108 * * *$ & $(0.0231)$ \\
\hline Listed built monuments in a $50 \mathrm{~m}$ radius (\#) & -0.001 & $(0.0005)$ & Located in neighborhood & $0.035^{* *}$ & $(0.0170)$ \\
\hline $\begin{array}{l}\text { Built in period before } 1905 \text { (ref: built in period } \\
\text { after 2000) }\end{array}$ & $-0.090^{* * *}$ & $(0.0115)$ & Located in neighborhood & -0.002 & $(0.0289)$ \\
\hline Built in period 1906-1930 & $-0.108^{* * *}$ & $(0.0112)$ & Located in neighborhood & & \\
\hline Built in period $1931-1944$ & $-0.120 * * *$ & $(0.0162)$ & Located in neighborhood & & \\
\hline Built in period $1945-1959$ & $-0.154^{* * *}$ & $(0.0305)$ & & & \\
\hline Built in period $1960-1970$ & $-0.158 * * *$ & $(0.0500)$ & Constant & $9.479 * * *$ & $(0.2720)$ \\
\hline Built in period 1971-1980 & $-0.143^{* * *}$ & $(0.0160)$ & & & \\
\hline Built in period 1981-1990 & $-0.146^{* * *}$ & $(0.0125)$ & & & \\
\hline Built in period $1991-2000$ & $-0.039 * * *$ & $(0.0123)$ & Observations & 5,114 & \\
\hline Built in unknown period & 0.060 & $(0.0629)$ & Adjusted R2 & 0.910 & \\
\hline
\end{tabular}

Note: Results from the other cases can be obtained from the author. Robust standard errors are reported between parentheses. $* \mathrm{p}<0.10 ; * * \mathrm{p}<0.05 ; * * * \mathrm{p}<0.01$. 


\section{Technical Appendix}

\section{Transformations of Industrial Heritage: Insights into external effects on house prices}

In the technical appendix, we give a (graphical) overview of each of the industrial heritages sites that are investigated in the paper, Transformations of Industrial Heritage: Insights into external effects on house prices. In Table 1 (copied from the paper), there is an overview of the five redeveloped industrial heritage sites that are investigated.

Table 1. Overview transformations of industrial heritage

\begin{tabular}{|c|c|c|c|c|c|c|c|}
\hline Case & & Original function & New function & $\begin{array}{r}\text { Start trans- } \\
\text { formation } \\
\text { year } \\
\end{array}$ & $\begin{array}{r}\text { End trans- } \\
\text { formation } \\
\text { year }\end{array}$ & $\begin{array}{r}\text { Surface } \\
\text { (ha) }\end{array}$ & $\begin{array}{r}\text { Costs (in } \\
\text { million } \\
\text { euros) }\end{array}$ \\
\hline $\begin{array}{l}\text { Westergasfabriek } \\
\text { Amsterdam } \\
\text { Populatie: } 810 \mathrm{k}\end{array}$ & WG & Gas factory & $\begin{array}{l}\text { Multifunctional: big } \\
\text { events, art exhibitions, } \\
\text { firms from the creative } \\
\text { sector, park }\end{array}$ & 2000 & 2003 & 13 & 66.5 \\
\hline $\begin{array}{l}\text { Villa Augustus } \\
\text { Dordrecht } \\
\text { Populatie: } 280 \mathrm{k}\end{array}$ & VA & Water tower & $\begin{array}{l}\text { Multifunctional: hotel, } \\
\text { restaurant, garden }\end{array}$ & 2005 & 2007 & 1.8 & 6 \\
\hline $\begin{array}{l}\text { Zaanse Chocoladefabriek } \\
\text { Zaandam } \\
\text { Populatie: 73k }\end{array}$ & ZC & $\begin{array}{l}\text { Bread / Chocolate } \\
\text { factory }\end{array}$ & $\begin{array}{l}\text { Multifunctional: firms } \\
\text { from the creative sector, } \\
\text { restaurant, fitness school }\end{array}$ & 2004 & 2009 & 1.9 & 10 \\
\hline $\begin{array}{l}\text { DRU Cultuurfabriek } \\
\text { Ulft } \\
\text { Populatie: } 11 \mathrm{k}\end{array}$ & DC & Iron foundry & $\begin{array}{l}\text { Multifunctional: local } \\
\text { events, theater, library, } \\
\text { art exhibitions }\end{array}$ & 2005 & 2009 & 14 & 14 \\
\hline $\begin{array}{l}\text { Wooncomplex Tricot } \\
\text { Winterswijk } \\
\text { Populatie: } 24 \mathrm{k}\end{array}$ & WT & Textile factory & $\begin{array}{l}\text { Residential housing and } \\
\text { cultural function: local } \\
\text { events }\end{array}$ & 2003 & 2006 & 0.9 & 21 \\
\hline
\end{tabular}

Note: This is an arbitrary selection based on 210 cases of redevelopment projects in the Netherlands. Our selection is based on size, popularity and on the cultural heritage aspects of the redevelopment project.

Source: www.kennisbankherbestemming.nu 


\section{Westergasfabriek (Amsterdam)}

The Westergasfabriek is a gas factory that was officially completed in 1885 . The factory produces gas that was used for street lighting. The location was strategically sited between water, rail and access roads. Due to the transformation to natural gas less coal gas was demanded and the Westergasfabriek closed in 1967. The $130000 \mathrm{~m}^{2}$ large area was then used for maintenance and storage until 1992. Already in 1981, the City of Amsterdam decided that the former site of the Western gas factory should become a green and recreational area. In 2000, the cleanup of the site started. Finally, the municipality was able to realize a park, Westerpark, which opened in 2003. The renovation of the real estate of the site was also finished in 2003. The cleanup project finished in 2008. These transformations were substantial and predominantly focused on the exterior of the industrial heritage site. The redevelopment cost around 66.5 million euro.

\footnotetext{
Source: Van Duijn, M., F. Lazrak, P. Rietveld, J. Rouwendal (2012). The effect of brownfield redevelopment on surrounding residential areas: The case of the Amsterdam Western gas factory, Working Paper.
}

\section{http://www.kennisbankherbestemming.nu/projecten/westergasfabriek-amsterdam}
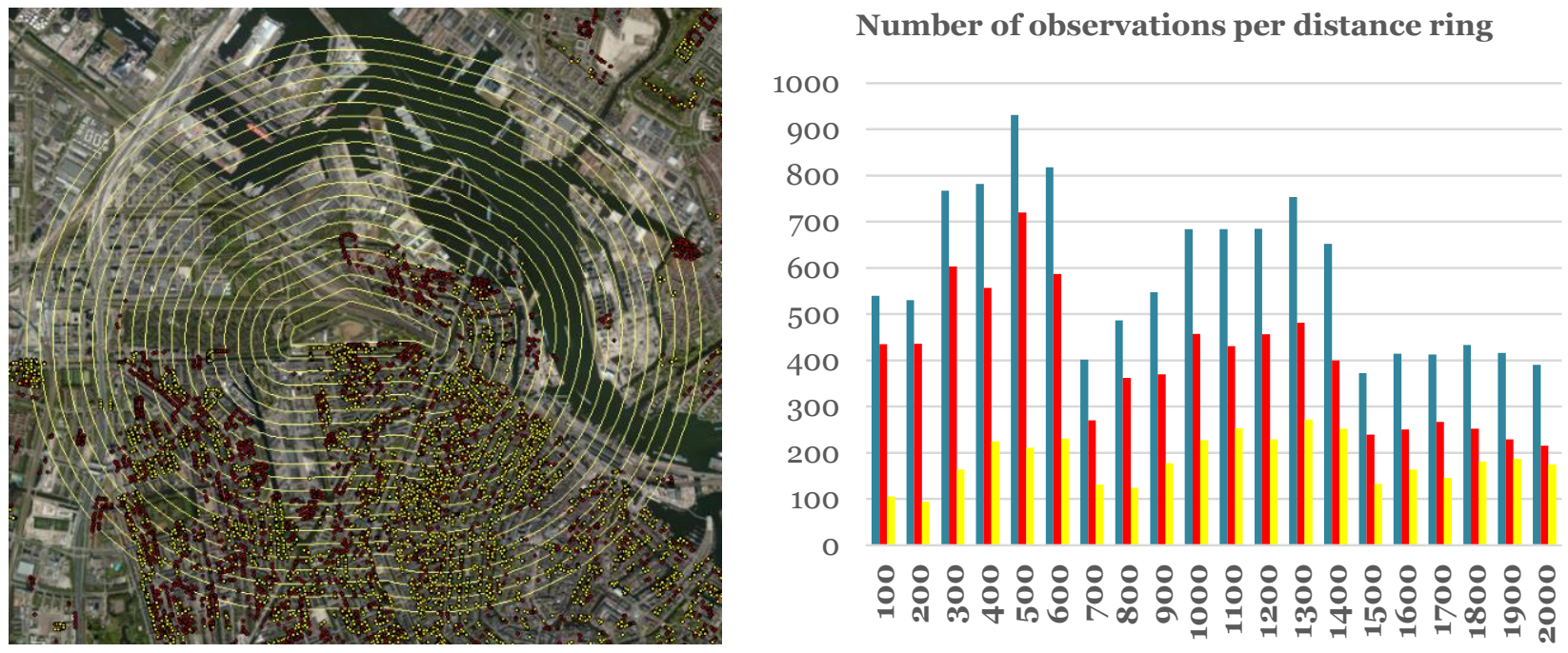

Figure A.WG. The location of the redeveloped industrial heritage site, Westergasfabriek, and the number of sold houses before (yellow) and after (red) the transformation (total is blue). 


\section{Villa Augustus (Dordrecht, east of Rotterdam)}

Villa Augustus is a former water tower and pumping station built in 1882, just outside (east) of the historic city center of Dordrecht. The industrial site is around $18000 \mathrm{~m}^{2}$ and has been redeveloped where they preserved the exterior of the old water tower. A hotel, restaurant and other firms from the catering sector are now located on the former industrial heritage site. The space between the tower and pumping station are converted to a kitchen garden, which is mainly used by the restaurant. Although, the garden may potentially have an effect on the quality of the neighborhood, the industrial area is surrounded by a, $2 \mathrm{~m}$ high, stone wall. The redevelopment cost around 6 million euro and was finished in 2007.

Source: http://www.kennisbankherbestemming.nu/projecten/villa-augustus-dordrecht

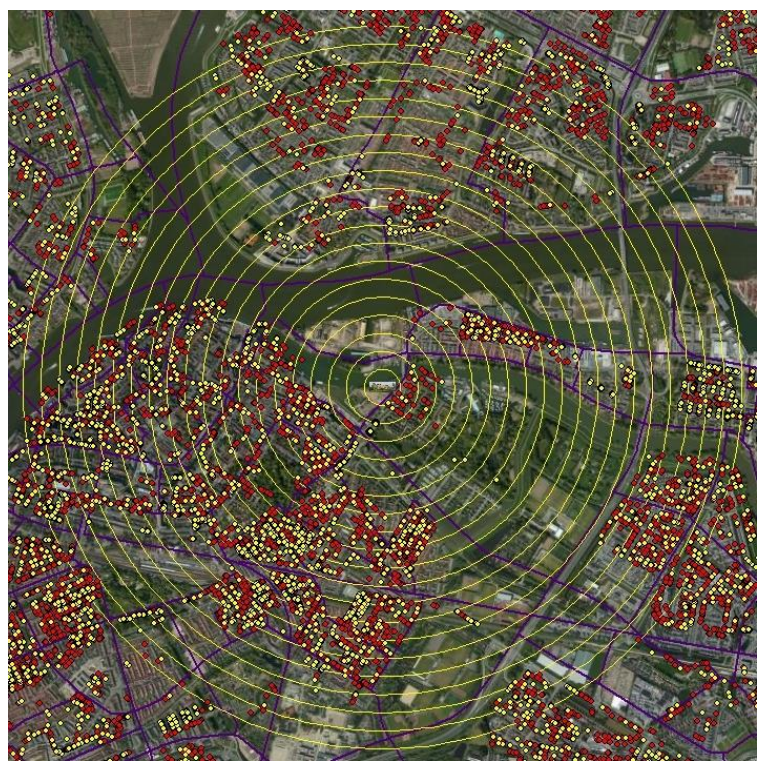

Number of observations per distance ring

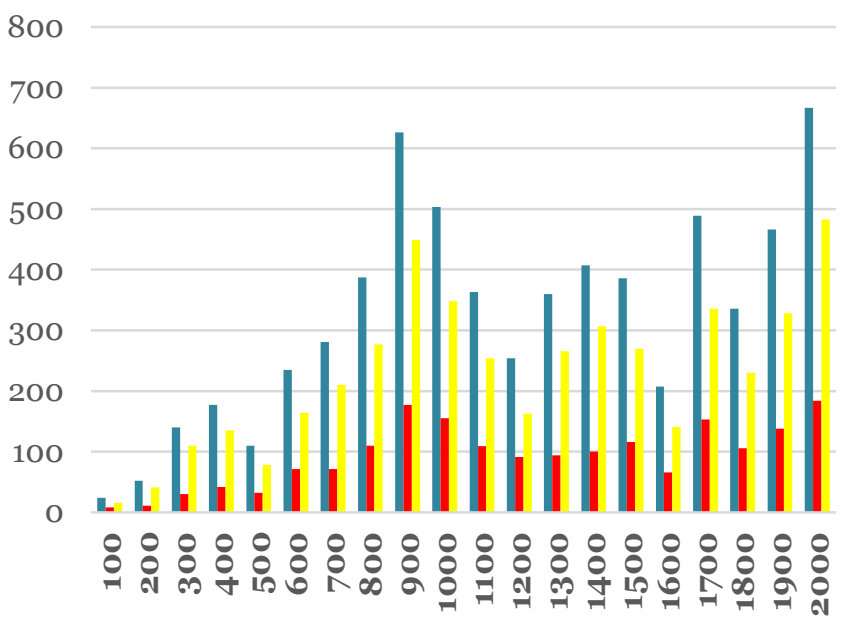

Figure A.VA. The location of the redeveloped industrial heritage site, Villa Augustus, and the number of sold houses before (yellow) and after (red) the transformation (total is blue).

Source: NVM, own computations. 


\section{Zaanse Chocoladefabriek (Zaandam, North of Amsterdam)}

The Zaanse Chocoladefabriek is a former industrial area, that started as a bakery built in 1886, in the middle of Zaandam. The site with a total floor space of $18000 \mathrm{~m}^{2}$ was abandoned in 2003. In 2004, the municipality and other partners decided that the factory should be redeveloped as a multifunctional building (for example, creative firms and a restaurant are located in the building). The costs of the redevelopment, which was - in my knowledge - mainly on the interior of the building, were around 10 million euro. The redevelopment was finished at the end of 2008.

Source: http://www.kennisbankherbestemming.nu/projecten/zaanse-chocoladefabriek-voorm-verkadefabriek
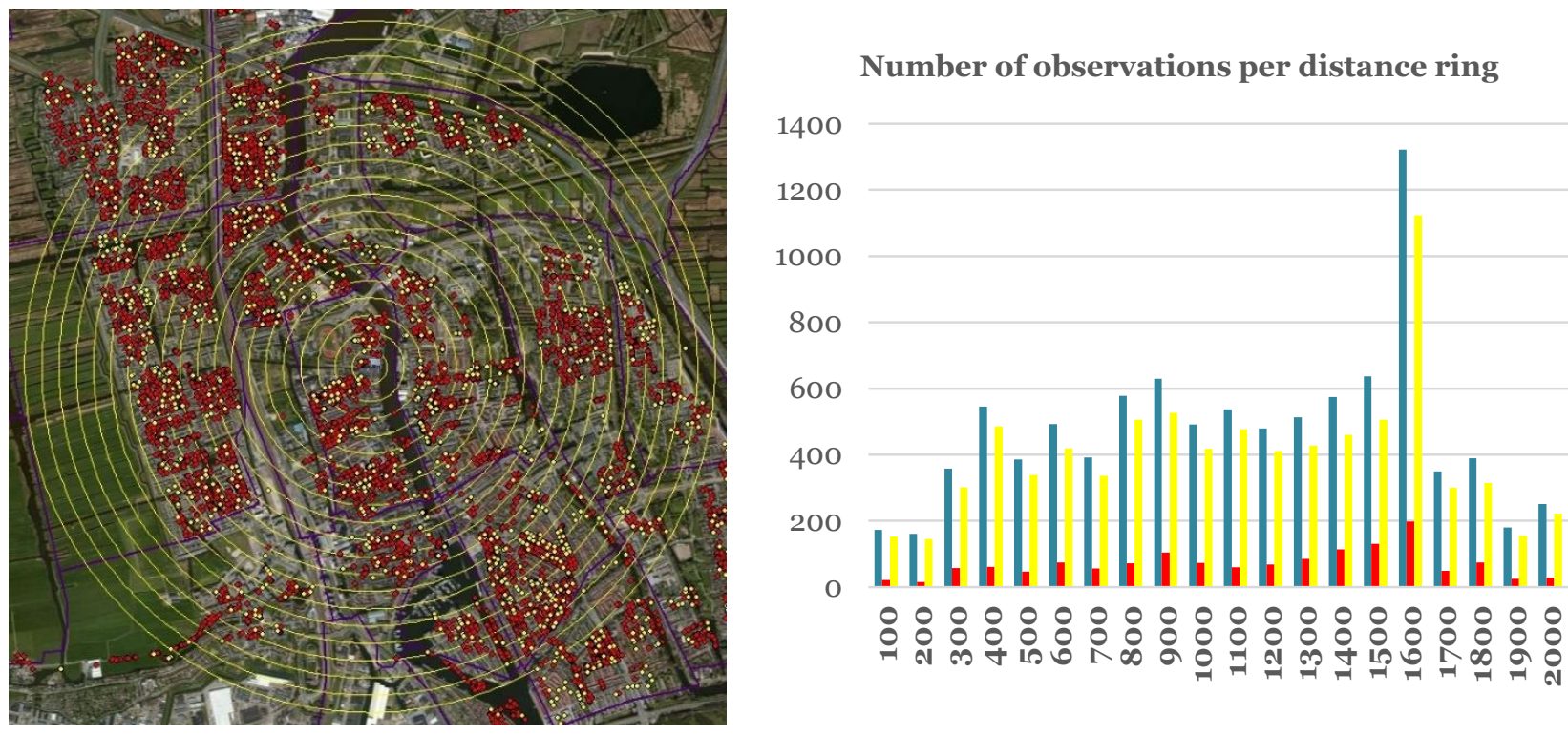

Figure A.ZC. The location of the redeveloped industrial heritage site, Zaanse Chocoladefabriek, and the number of sold houses before (yellow) and after (red) the transformation (total is blue).

Source: NVM, own computations. 


\section{DRU Cultuurfabriek (Ulft, located in the eastern part of the Netherlands)}

The DRU Cultuurfabriek is a former industrial area, which started as a factory that made iron objects built in 1754, in a small town, Ulft. In 1989 the factory with a total of floor space of 14000 $\mathrm{m}^{2}$ was abandoned. In 1997, there were plans made to redevelop the industrial heritage site without losing its industrial (historical) identity. In 2009, the redevelopment of the interior of the factory was finished. The former factory is now a multifunctional building where a new theater, library, art gallery, schools and other cultural events are located. Recent plans were made to redevelop the exterior of the industrial heritage site.

Sources: http://www.kennisbankherbestemming.nu/projecten/dru-cultuurfabriek-te-ulft

Case rapport transformatie DRU Industrieterrein, in "De Economische Waardering van Monumentaal Vastgoed", door de Stad bv \& Platform 31.
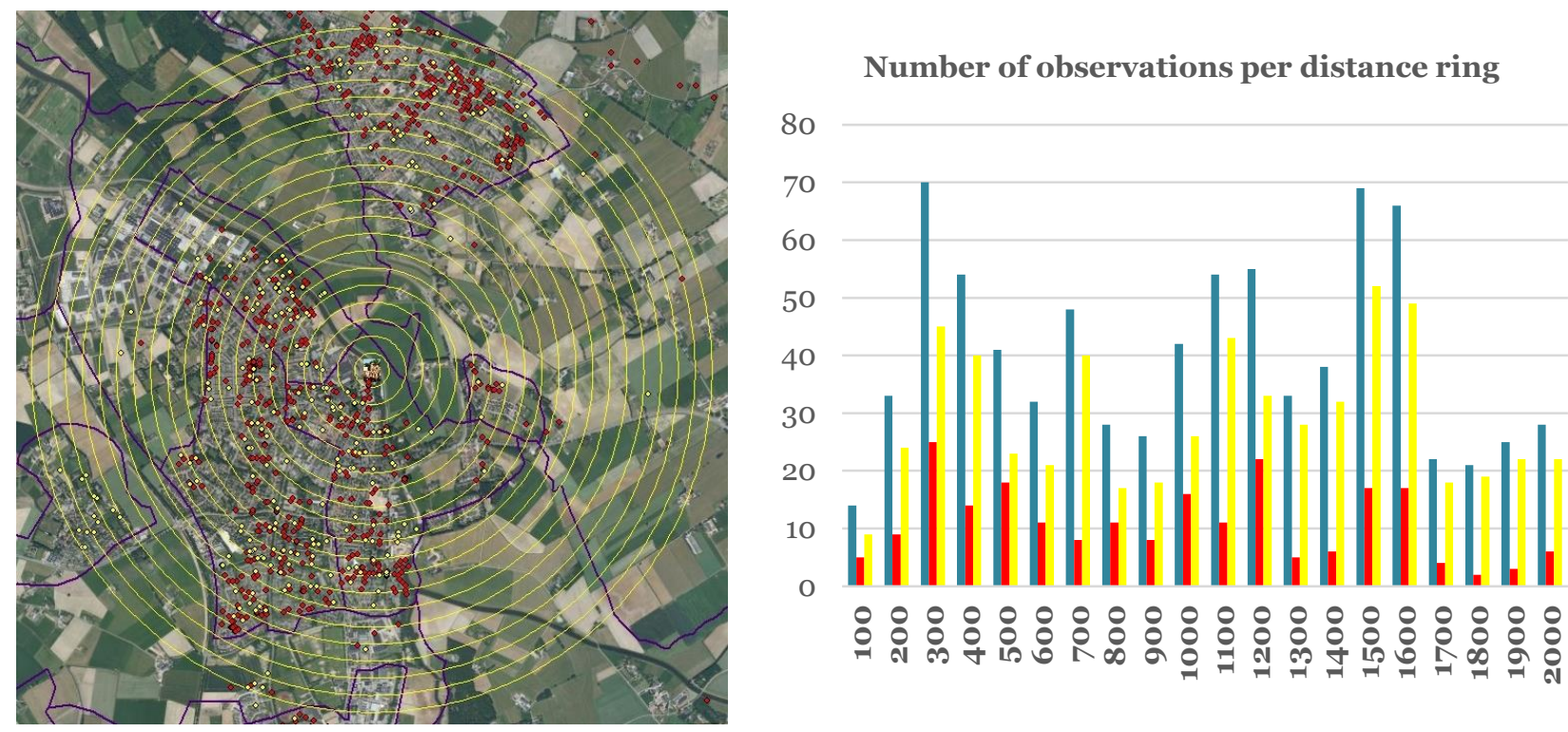

Figure A.DC. The location of the redeveloped industrial heritage site, DRU Cultuurfabriek, and the number of sold houses before (yellow) and after (red) the transformation (total is blue).

Source: NVM, own computations. 


\section{Wooncomplex Tricot (Winterswijk, located in the eastern part of the Netherlands)}

Wooncomplex Tricot is a former textile factory built in 1890 . The site is characterized by a $36 \mathrm{~m}$ high chimney. There were plans to demolish and rebuilt the whole area of $9000 \mathrm{~m}^{2}$, until it became a national listed monument. The real estate was renovated and the exterior was adjusted to modern standards. The real estate is now used for residential housing. From a historical perspective, the most important thing was to preserve the chimney. The exterior changed somewhat regarding the real estate and the public space, but the industrial character of the site remained. The costs of redevelopment were around 21 million euro. The redevelopment of the real estate to residential housing finished in 2006.

\section{Sources: http://www.kennisbankherbestemming.nu/projecten/wooncomplex-tricot-winterswijk}
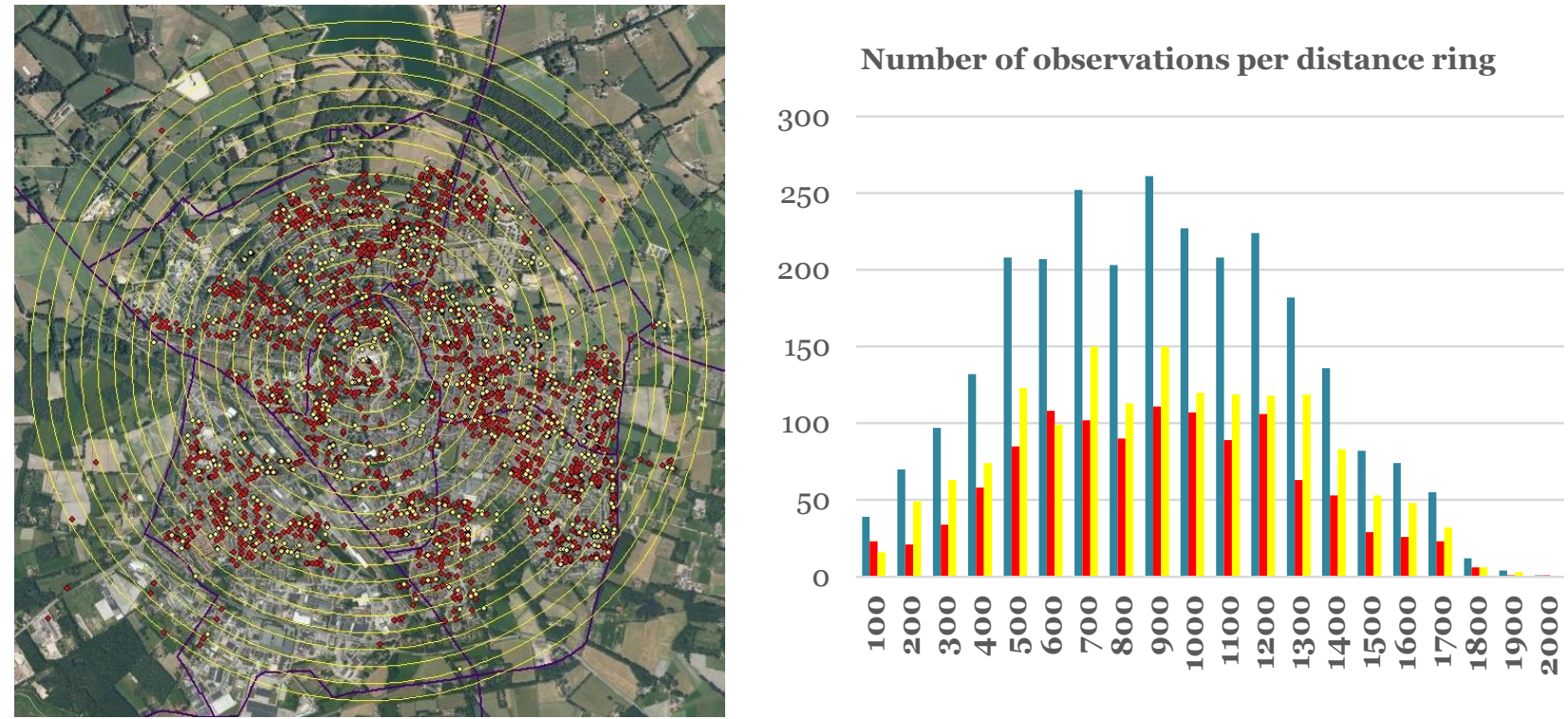

Figure A.WT. The location of the redeveloped industrial heritage site, Wooncomplex Tricot, and the number of sold houses before (yellow) and after (red) the transformation (total is blue). 